\title{
Building Technology Project Summaries
}

\section{9-1980}

\section{Al1100 985501}

NB:

PUBLICA:

A11100985501

United States. Natlo/Bullding technology 197

QC100 .U57 V446-4;1980 C.2 NBS-PUB-C 197

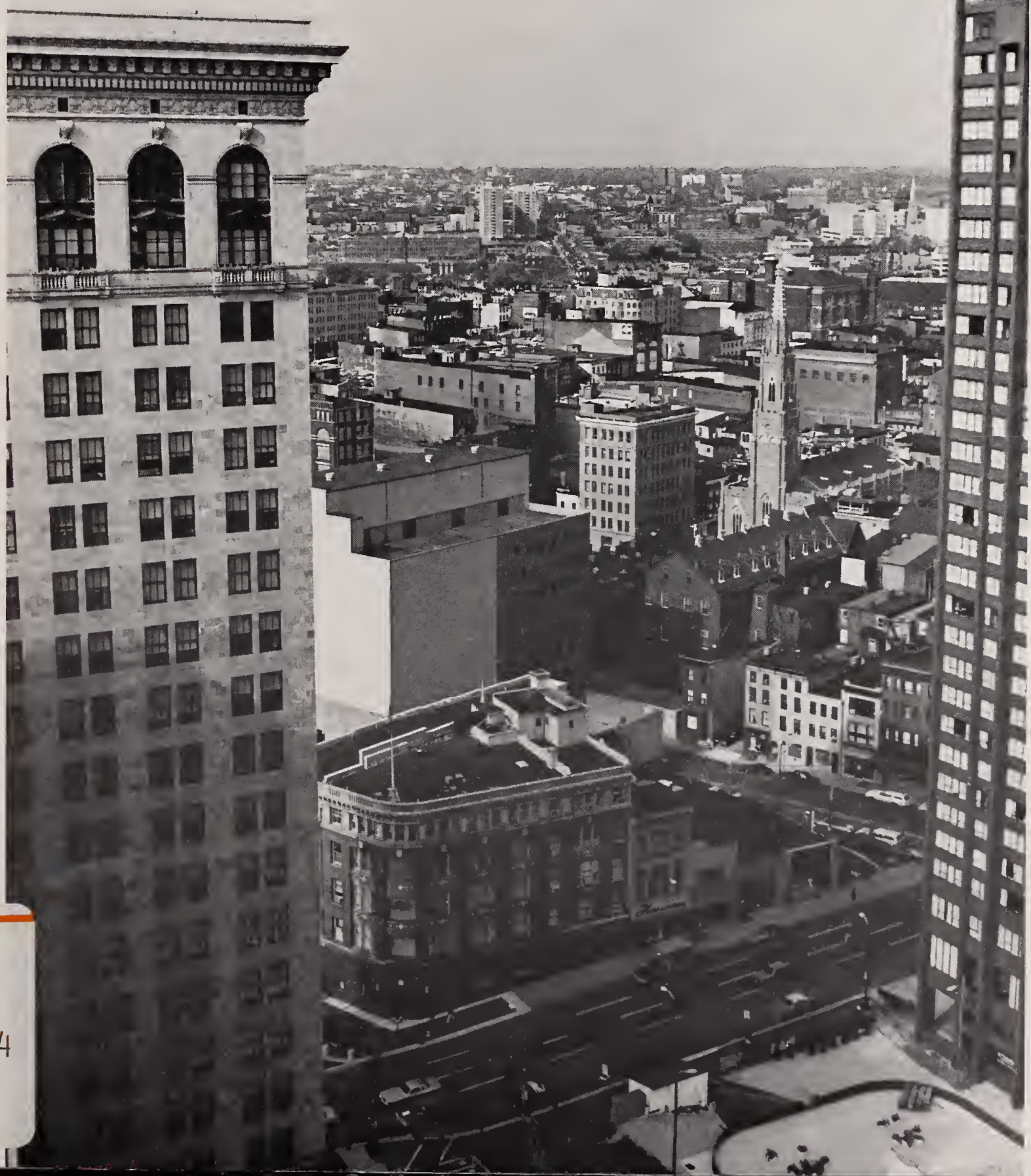





\section{Building Technology \\ Project Summaries}

Hatlonal Bureas of Standaress

Library, F.01 Aưmin. Rildg.

$1979-1980$

\section{SEP $12 \uparrow 980$}

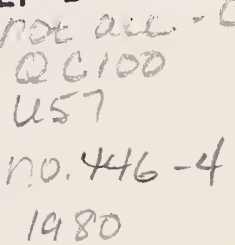

NBS SP 446-4

Editors:

Noel Raufaste

Michael Olmert

Center for Building Technology

National Engineering Laboratory

National Bureau of Standards

U.S. Department of Commerce

Washington, D.C. 20234

U.S. DEPARTMENT OF COMMERCE, Philip M. Klutznick, Secretary

Luther H. Hodges, Jr., Deputy Secretary

Jordan J. Baruch, Assistant Secretary for Productivity, Technology and Innovation 


\section{Library of Congress Catalog Card Number: 80-600133}

\section{National Bureau of Standards Special Publication 446-4}

Nat. Bur. Stand. (U.S.), Spec. Publ. 446-4, 79 pages (July 1980)

$$
\text { CODEN: XNBSAV }
$$




\section{Foreword}

The Center for Building Technology's (CBT) mission is to increase the usefulness, safety, and economy of buildings through the advancement of building technology and its application to the improvement of building practice. CBT's research activities support the building technology programs of Federal, State, and local governments; assist design professions, building officials, and the research community by developing improved design criteria; and assist manufacturers of building products by developing methods for evaluating innovative materials, components, and systems.

CBT's research is aimed at developing the necessary technology to assist in reducing the annual growth of total national energy demand to below 2 percent and the projected level of energy demand by 2.8 million barrels of oil equivalent per day by 1985 ; reduce accidental deaths, injuries, and property losses in building construction by 20 percent in 20 years; and increase building productivity by 10 percent in 15 years. Thus, CBT's programs address energy conservation, building safety, and building productivity and performance. Typical CBT activities include: investigating failures, such as the Willow Island cooling tower accident, to determine causes and needs for improved practices; improving measurement techniques, such as development of accurate equipment to measure the performance of thick insulation; defining characteristics of building performance, such as human response to time-varying noise; and developing methods for comparing benefits and costs, such as life-cycle cost approaches for selecting optimal energy retrofit measures. All these activities are conducted in cooperation with other organizations in the building community that participate in the studies or are affected by the results.

NBS/CBT does not promulgate building codes or standards. CBT provides an objective source of technical information for national consensus standards and model code organizations. Close cooperation with these groups leads to standard practices that meet the needs of the regulatory authorities of State and local governments. Research providing the knowledge for these standard practices is conducted in cooperation with government, university, and industry laboratories.

This report summarizes CBT's research for 1979-1980. Each summary lists the project title, its progress, point of contact within CBT, and sponsor.

The summaries are arranged according to the 11 prime research areas that comprise the scope of work at CBT, which is shown on page xi. This year the report also features a Building Community Index (p. 74), which keys CBT research to individual segments of the industry. 
The reader is encouraged to review two companion documents: 1) NBS Special Publication 439, The Center for Building Technology: A Perspective, which presents the Center's approach to building research and its facilities; and 2) NBS Special Publication 457, Building Technology Publications, and its supplements. 


\section{Contents}

\section{Energy Conservation in Buildings}

11

12

13

\section{Building Thermal Envelope} Systems and Insulating Materials
2 Energy Analysis: Norris Cotton Building Energy Analysis Procedures

Energy Audit Procedures for Commercial Buildings Dynamic Performance of HVAC Systems and Controls

EMCS Reliability Study

EMCS Computer Modeling

4 Energy Analysis of Control Strategies

Retrofit Instrumentation Technology/EMCS Sensors

Thermostat Test Standard

Evaluating the Performance of Heat Pumps

Heat Pump Studies

Part-Load Performance of HVAC Equipment

Furnace Studies

Central Air Conditioner Studies

Central Air Conditioner Test Procedures

Technical Evaluation Manual for Energy Conservation

Building Energy Performance Criteria

Retrofit Training Criteria

Revision of Bioclimatic Chart

Daylighting Studies

Daylighting Prediction Methodology

NFC Research Associate Program (Daylighting)

Life-Cycle Cost Methodology

Cost-Effectiveness of Infrared Heat-Loss Surveys

(Ground-Based)

Infrared Aerial Survey Evaluation

Weatherization Demonstration

Building Infiltration Evaluation

2 Guidelines for Controlling Attic Condensation

Modeling Cooling with Whole-House Fans

Underground Heat Distribution Systems

3 Energy Conservation Through Waste Use in Cement and Concrete

16 Thermal Insulation Standard Reference Material Thermal Insulation Analysis Thermal Insulation Test Series

Thermal Performance of Materials and Elements

17 Modeling Mass Effects with Outside Insulation Experimental Evaluation of Thermal Mass

18 MIMA Research Associate Program Guarded Hot-Plate Tester for Thick Insulation Calibrated Hot Box Construction Corrosion Avoidance in Encapsulated Wiring

19 Retrofit Criteria: Insulation and Wiring

Building Solar Systems Technology 22

Collector Durability and Reliability Test Program Standards for Rubber Hose and Connections

23 Standards for Solar Cover Plates

Standards for Nonmetallic Containment Materials 
24 Standards for Solar Absorptive Coatings

Evaluation of IPC Corrosion Test Methodology

Solar Hot Water System Test Program

25 Structural Performance of Solar Collectors

Thermal Test Methods for Solar Collectors

Passive Solar Data Requirements

26 Economic Evaluation of Passive Solar Designs for Urban Environments

Installation of Solar Components on Roofs

Solar Evaluation of the Norris Cotton Building

27 Monitoring Methods for Low-Cost Residential Solar Systems

Commercial Solar Energy Demonstration

Solar Energy Program for Housing Systems

28 Dimensional Considerations in Solar Installation

Solar Federal Buildings Program

Federal Procurement Specifications for Solar Heating and Cooling

29 Economic Optimization Guide for Solar Systems in Federal Buildings

Technical Evaluation Manual for Solar Retrofit of Federal Buildings

International Cooperation in Solar Energy

Residential Solar Data Center

30 Development of Solar Regulatory Provisions

Code Analysis of Thermal Energy Storage

31 Solar Utilization in Cities and Towns

Combined Photovoltaic/Thermal Solar Systems

Earthquake Hazard Reduction

Structures and Foundations Performance
34 Characterization of Structural Response to Earthquakes Seismic Provisions for Buildings

35 Characterization of Soil and Foundation Response to Earthquakes

Romania Earthquake Rehabilitation

Loading Criteria for Structural Design

Development of Revisions to

American National Standards Institute A58

Application of Reliability Analysis Concepts to Building Components

39 Construction Load Evaluation

Concrete Construction Technology

Mechanical Properties of Maturing Concrete

Snow Loads on Nuclear Power Plant Structures

40 Criteria for Design of Cladding Subjected to Wind Loads

Criteria for Wind Tunnel Modeling

41 Measurement of Forces on Trench Bracing

Construction Practice in Excavation

Standards for Foundations and Excavations

42 In-Situ Geotechnical Measurements

Construction of the NBS Geotechnical Test Lab

Mobile Home Anchoring Against Flood and Windloads

Anchoring Mechanics for Mobile Homes

43 Review of Design Criteria for Energy Transport Systems 
44 Short-Term Evaluation of Steel Coatings

Stone Consolidating Materials

Evaluation of Joint Sealants for the Dirksen Building

45 Nondestructive Evaluation of Building Materials

Elastomeric Roofing Membranes

Roofing and Coatings Research for the Army

46 Blistering of Built-Up Roofing over

Polyurethane Insulation

Tri-Services Technical and Scientific Support

Improvement of Honeycomb Sandwich Panels

Building Safety

48 Criteria for Signs in Workplaces

Chromaticity Specifications for Color Weather

Radar Displays

Symbols Criteria and Standardization

49 Security Barriers

\section{Building Rehabilitation Technology}

Construction Productivity for New and Rehabilitated

Buildings

Methods for Evaluating the Strength and Stability of

Existing Buildings

Regulatory Provisions for Existing Buildings

53 Performance Levels for Existing Buildings

Ventilation Criteria for Existing Buildings

54 Restoration Standards for Porcelain Finishes

Metric Conversion Scheduling in the

U.S. Building Community

Design and Construction Technology

Application Program

Building and Community Acoustics

Building Acoustics Technology

Highway Noise Criteria

Transmission Line Audible Noise Measurement

59 Impact Noise Measurement

Sound Absorption Measurement

60 Method for Assessing Costs of a Model

Noise-Control Code 
Lighting Technology

Building Economics

Building Community Index
66 Lighting Design Evaluation Task Lighting Criteria

Measurement of Illumination Systems Effectiveness

Laboratory and Field Illumination Measurements

67 Applied Color and Vision

Visual Environment

Visual Techniques in NDE

70 Economic Methods for Building Standards

Economic Impact of Electronics Research

Quantitative Optimization Techniques

71 Economics Participation in Conferences, Workshops, and Seminars

73 


\section{Abbreviations Used in the Text}

\begin{tabular}{|c|c|}
\hline $\mathrm{ACF}$ & Area Cost Factors \\
\hline AID & Agency for International Development \\
\hline ACI & American Concrete Institute \\
\hline AIA & American Institute of Architects \\
\hline AIARC & AIA Research Corporation \\
\hline ANMC & American National Metric Council \\
\hline ANSI & American National Standards Institute \\
\hline ARI & American Research Institute \\
\hline ASPE & American Society of Plumbing Engineers \\
\hline ASSE & American Society of Sanitary Engineers \\
\hline ASTM & American Society for Testing and Materials \\
\hline ASHRAE & $\begin{array}{l}\text { American Society for Heating, Refrigerating, } \\
\text { and Air-Conditioning Engineers }\end{array}$ \\
\hline ASME & American Society for Mechanical Engineers \\
\hline BECC & Building Energy Conservation Criteria \\
\hline BFIRES & $\begin{array}{l}\text { A Computer Program Dealing with Human } \\
\text { Performance During Building Fires }\end{array}$ \\
\hline BLAST & An Energy Analysis Computer Program \\
\hline BOCA & $\begin{array}{l}\text { Building Officials and Code Administrators } \\
\text { International, Inc. }\end{array}$ \\
\hline BRAB & Building Research Advisory Board \\
\hline BUR & Built-up Roofing \\
\hline CBT & Center for Building Technology \\
\hline CERL & Construction Engineering Research Laboratory (U.S. Army) \\
\hline CFR & Center for Fire Research \\
\hline CIB & $\begin{array}{l}\text { International Council for Building Research, } \\
\text { Studies, and Documentation }\end{array}$ \\
\hline $\mathrm{CICC}$ & Construction Industries Coordinating Committee \\
\hline CSA & Community Service Administration \\
\hline CPSC & Consumer Product Safety Commission \\
\hline DoE & Department of Energy \\
\hline EDA & Economic Development Administration \\
\hline EIA & Energy Information Agency \\
\hline EMCS & Energy Monitoring and Control Systems \\
\hline EPA & Environmental Protection Agency \\
\hline FAA & Federal Aviation Administration \\
\hline $\mathrm{FCC}$ & Federal Construction Council \\
\hline FEMA & Federal Emergency Management Agency \\
\hline FERC & Federal Energy Regulatory Commission \\
\hline FmHA & Farmers Home Administration \\
\hline FHWA & Federal Highway Administration \\
\hline FIRL & Franklin Institute Research Laboratories \\
\hline GSA & General Services Administration \\
\hline HEW & Department of Health, Education, and Welfare \\
\hline HUD & Department of Housing and Urban Development \\
\hline HVAC & Heating, Ventilation, and Air-Conditioning \\
\hline ICBO & International Conference of Building Officials \\
\hline IEEE & Institute of Electrical and Electronic Engineers \\
\hline IERI & Illumination Engineering Research Institute \\
\hline IES & Illumination Engineering Society \\
\hline ISO & International Standards Organization \\
\hline LBL & Lawrence Berkeley Laboratory \\
\hline $\mathrm{LCC}$ & Life-Cycle Costing \\
\hline
\end{tabular}




$\begin{array}{ll}\text { LNG } & \text { Liquid Natural Gas } \\ \text { MIMA } & \text { Mineral Insulation Manufacturer Association } \\ \text { MIUS } & \text { Modular Integrated Utility Systems } \\ \text { MPS } & \text { Minimum Property Standards } \\ \text { NAHB } & \text { National Association of Home Builders } \\ \text { NBS } & \text { National Bureau of Standards } \\ \text { NBSLD } & \text { National Bureau of Standards Load Determination } \\ & \text { (A Computer Program) } \\ \text { NCSBCS } & \text { National Conference of States on Building Codes } \\ & \text { and Standards } \\ \text { NDE } & \text { Nondestructive Evaluation } \\ \text { NEC } & \text { National Electric Code } \\ \text { NEMA } & \text { National Electrical Manufacturers Association } \\ \text { NFPA } & \text { National Fire Protection Association } \\ \text { NIBS } & \text { National Institute of Building Sciences } \\ \text { NIOSH } & \text { National Institutes of Occupational Safety } \\ & \text { and Health } \\ \text { NOAA } & \text { National Oceanic and Atmospheric Administration } \\ \text { NPS } & \text { National Park Service } \\ \text { NRC } & \text { National Research Council (Canada) } \\ \text { NSF } & \text { National Science Foundation } \\ \text { ORNL } & \text { Oak Ridge National Laboratory } \\ \text { OSHA } & \text { Occupational Safety and Health Administration } \\ \text { RCS } & \text { Residential Conservation Service } \\ \text { RIF } & \text { Resource Impact Factors } \\ \text { RILEM } & \text { International Union of Testing and Research } \\ & \text { Laboratories for Materials and Structures } \\ \text { RSV } & \text { Reduced-Size Venting } \\ \text { SAE } & \text { Society for Automotive Engineers } \\ \text { SERI } & \text { Solar Energy Research Institute } \\ \text { SPT } & \text { Standard Penetration Tests } \\ \text { SRM } & \text { Standard Reference Materials } \\ \text { UF } & \text { Urea-Formaldehyde } \\ \text { USGS } & \text { United States Geological Survey } \\ \text { USNC/CIB United States National Committee/International } \\ & \text { Council for Building Research, Studies, and } \\ \text { UV } & \text { Documentation } \\ \text { VA } & \text { Veterans Administration } \\ & \end{array}$




\section{CENTER FOR BUILDING TECHNOLOGY}

CENTER HEADQUARTERS

\section{Structures and \\ Materials \\ Division \\ Earthquake Hazard Reduction \\ Construction Safety \\ Geotechnical \\ Engineering \\ Structural \\ Engineering \\ Building Materials \\ Building Composites}

\section{Building Thermal Performance Division}

Thermal Analysis

Thermal Solar

Building Energy Criteria

Thermal Insulation

\section{Environmental \\ Design Research \\ Division}

Architectural Research

Sensory Environment

Building Safety

Building and Community Acoustics

Building Economics and Regulatory Technology Division

Applied Economics

Rehabilitation Technology

Solar Technology

Criteria and

Standards Development

Building Equipment

Division

Thermal Machinery

Systems and Controls

Service Systems 

Energy

Conservaknon

ปัn Budidings

\section{Energy}

Conservation

in Buildings

Energy

Conservaknon

in Buiddinges

Energy

Conservation

inc Buoidilings

Energy

Conservaknon

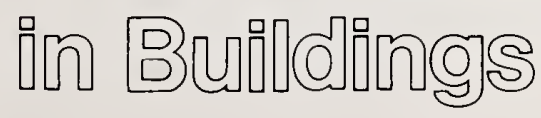

Energy

conservantion

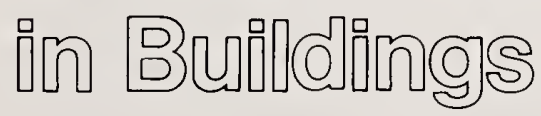




\section{Energy Analysis: Norris Cotton Building}

Thomas E. Richtmyer

(301) 921.3602

Building Thermal and Service Systems

Division

Sponsor: Department of Energy
GSA's Norris Cotton Federal Office Building in Manchester, N.H., has been designed to demonstrate a number of energy-saving concepts. For this reason, it uses a variety of equipment, such as heat pumps, modular boilers, an engine/generator with waste heat recovery, solar collectors, liquid thermal storage, and special lighting. Exterior walls are of heavy masonry construction with an outer insulating layer to create a "thermal flywheel," thereby reducing peak heating and cooling loads. The windows are double-glazed and occupy a relatively small fraction of the exterior facade. Fin-like granite panels surround the windows and are fixed in a position that reflects in sunlight during winter, blocks out sunlight in summer, and breaks up strong winds. Of the building's seven floors, no two are the same. Each one has some variation in its mechanical equipment, lighting, and/or window arrangement.

Employing several different energy-saving concepts will, of course, have value only if each is assessed individually for its effectiveness.

A computer data-acquisition system has been installed on site that senses critical temperatures, fluid flows, and electrical power throughout the building and records this information on magnetic tape. These tapes are then sent to CBT where they are processed by a UNIVAC 1108 computer. The output is a breakdown of energy usage within the building. Also, computer simulations are performed for the purpose of evaluating the effectiveness of the equipment as it is currently operated. This simulation program is also being used to study the effects of system modifications.

The success of the Building Energy Performance Standard hinges on the availability of accurate, yet easy to use, energy analysis procedures. Although DoE has identified the DoE-2 program as the standard benchmark energy analysis procedure, this particular program is not suitable for use by practicing engineers and energy officials because of its complexity and its requirement for large computers. This project will provide the criteria for certifying commercial and useable energy analysis procedures, which would result in an annual energy consumption estimate compatible with that produced by DoE-2. 


\section{Energy Audit Procedures for Commercial Buildings}

Tamami Kusuda

(301) 921-3501

Building Thermal and Service Systems

Division

Sponsor: National Bureau of Standards

\section{Dynamic Performance of HVAC Systems and Controls}

George Kelly

(301) 921-3839

Building Thermal and Service Systems

Division

Sponsor: National Bureau of Standards

\section{EMCS Reliability Study}

K. Yee

(301) 921-3311

Building Thermal and Service Systems

Division

Sponsor: Department of Energy

\section{EMCS Computer Modeling}

James Y. Shih

(301) 921-2144

Building Thermal and Service Systems

Division

Sponsor: Department of Energy and Department of the Navy
The first step in implementing the energy conservation retrofit of existing buildings is to determine needed improvements to the building, its HVAC systems, and its operation. To advise the building owner, an effective energy audit procedure must be used to accurately predict the tradeoff between the energy savings benefit and required cost for implementing the suggested options. Numerous audit procedures are already in existence in State and Federal Governments and the private sector. However, none has achieved general acceptance as a standard approach and many lack a suitable procedure for prioritizing from among the many retrofit options that may be presented by a given building. This project will provide such an audit procedure.

To address the effect of control dynamics on energy consumption, space conditions, and comfort, laboratory tests will be carried out on many of the individual components comprising the most common HVAC systems and controls. Models will be developed for these components, verified through laboratory testing, and used to generalize the results to typical field applications. Components whose performance could be studied include induction systems, fan coil units, double duct mixing boxes, variable volume boxes, and their respective discharge air temperature control systems. Work will begin in FY80 on one or more of the most commonly used systems and their related controls, and will be broadened in FY81 to include other types of HVAC system controls.

This project will concentrate on improving energy monitoring and control systems (EMCS). It will survey failures in existing EMCS systems and relate the failure data to several areas of concern: components, systemwide problems, manufacturing process, and software issues. Problems will be grouped into those with known remedies and without remedies. Recommendations will be prepared for enhancing reliability.

Most of the existing conservation algorithms, on which energy monitoring and control systems (EMCS) operations are based, have limited capabilities associated with rudimentary schemes for enhancing thermal efficiency. Identification of the algorithms used in existing systems and of energy savings opportunities not yet employed is needed. Under this project, algorithms for advanced energy conservation methodology using EMCS will be reported. The logic flow and advantages will be explicitly documented. 


\section{Energy Analysis of Control Strategies}

George Kelly

(301) 921.3839

Building Thermal and Service Systems

Division

Sponsor: Department of Energy

\section{Retrofit Instrumentation Technology/EMCS Sensors}

James Y. Kao

(301) 921-3844

Building Thermal and Service Systems

Division

Sponsor: Department of Energy and Department of the Navy

\section{Thermostat Test Standard}

James Y. Kao

(301) 921-3844

Building Thermal and Service Systems

Division

Sponsor: Department of Energy
Under this project, the computer programs DOE-2 or BLAST-2 will be used to document the energy savings attributed to the use of different, commonly employed HVAC control strategies for a variety of HVAC systems, building types, and climatic regions. Typical strategies that will be studied include: economizer cycle with and without enthalpy control, hot and cold deck temperature reset, floating space conditions, resetting of set points, and optimum start/stop. In addition, a small contract will be let to evaluate different approaches to the development of a computer simulation model capable of predicting the effect of short-term (minute-by-minute) control dynamics and evaluating the benefits of advanced control strategies. The outcome of both of the above tasks will be used to formulate the direction and shape of NBS/DoE controls program in FY81.

This project will investigate and recommend suitable sensors and instrumentation technology for application to energy monitoring and control systems (EMCS). An increasing number of commercial and institutional buildings are being built or retrofitted with EMCS systems as an energy conservation tool. Decisions are made by the building owners and operators to repair or replace energy-using equipment, based on data obtained from EMCS. The accuracy and precision of feedback information affects the ability to maintain desired operating modes and conditions. If the uncertainties of the measured quantities and energy rates are not properly accounted for in specifying the system, the energy efficiency may be impaired and information based on maintenance or replacement measures may not be valid.

This project will develop a thermostat test procedure and standard. Most heating and cooling systems installed in houses and small buildings use on-off electric thermostats for temperature regulation. An important part of a closed control loop, the thermostat interacts with the heating and cooling plant, the building thermal characteristics, and load changes (internal and external) to give dynamic variations in space temperature. Although each component of this loop influences the temperature level and the energy consumption of the building, it is essential that the behavior of the thermostat be known and analyzed to have an accurate prediction of the energy consumption of the building. 


\section{Evaluating the Performance of Heat Pumps}

David A. Didion

(301) 921-2994

Building Thermal and Service Systems

Division

Sponsor: Department of Energy

Heat Pump Studies

George Kelly

(301) 921-3839

Building Thermal and Service Systems

Division

Sponsor: Department of Energy

\section{Part-Load Performance of HVAC Equipment}

David A. Didion

(301) 921.2994

Building Thermal and Service Systems

Division

Sponsor: Department of Energy
The first objective of this study is to determine the significance of the start-up, shut-down dynamics on the energy performance of an absorption air conditioner of residential size. If the dynamics prove significant (as is anticipated) the second objective will be to transform the NBS steady state evaluation standard (under draft review) into one that will include these dynamic effects. CBT will conduct a series of cyclic tests on a new 3-ton ARKLA "solar" water-fired absorption air conditioner. The results of the tests will be analyzed for two effects. First, does the magnitude of the degradation of the unit's performance due to dynamics have a significant effect on the seasonal performance rating in a typical installation? Second, are the unit's shut-down, start-up capacity transients such that they may be simulated by a single- or double-time constant model.

The current test procedure requires manufacturers to test an outdoor coil/compressor section with the indoor coil they sell most. This reduces the amount of testing required, but causes problems when manufacturers want to make representations regarding the performance of other size (or type) indoor coils with that outdoor section. CBT will develop a procedure that will enable manufacturers to use the laboratory data from one indoor/outdoor coil combination to predict the performance likely to result from using other indoor coils with the outdoor section tested. Work will also continue on the field performance of three heat pumps in the Washington, D.C. area.

This project will establish the dynamic performance and part-load efficiency characteristics of large HVAC equipment for design simulation codes and for background data for minimum standards. Since the start of this project in 1977, an additional activity under the sponsorship of ASHRAE has become significant and is of such similar nature (although much broader in scope) that it has been convenient to incorporate the NBS/DoE support under the ASHRAE project. This ASHRAE activity is the Task Group on Building Dynamics. The ultimate goal of this Task Group is the documentation of the energy performance optimization of building operations, predominately through control systems. The heart of this effort will be another type of building simulation code, but many of the component algorithms (such as equipment) will be similar to the building design simulation codes. 


\section{Furnace Studies}

George Kelly

(301) 921-3839

Building Thermal and Service Systems

Division

Sponsor: Department of Energy

\section{Central Air Conditioner Studies}

George Kelly

(301) 921-3839

Building Thermal and Service Systems

Division

Sponsor: Department of Energy

\section{Central Air Conditioner Test Procedures}

George Kelly

(301) 921-3839

Building Thermal and Service Systems

Division

Sponsor: Department of Energy
The Energy Policy and Conservation Act (PL 94-163) and the National Energy Act require the Department of Energy to prescribe test procedures and minimum performance standards, respectively, for residential furnaces and boilers. These laws state that the National Bureau of Standards shall help DoE develop these regulations. Final test procedures for furnaces and boilers were published in the Federal Register on May 10, 1978. DoE is refining these test procedures and setting minimum standards.

CBT will develop a computer model to evaluate the effect of furnace or boiler location on seasonal performance and annual operating cost. It will be designed to cover installation in indoor living areas, indoor closets, outdoor closets, outdoors, and in "unheated" basements. The model will be verified by conducting experimental studies on a mobile home located in CBT's large environmental chamber. This research will include evaluating off-period losses for direct vent, non-power burner furnaces using the optional "tracer gas" testing procedure; determining the effect of jacket losses and fuel modulation on a "finned tube" boiler; and recommending modification of test procedures for automatic stack dampers to include electric operated units that employ a time delay prior to closing. CBT's recommendations to DoE will also address minimum efficiency standards for furnaces and boilers.

This project will undertake the development and verification of a computer model for a central air conditioner that can be used by manufacturers to reduce the amount of laboratory testing required under the existing test procedures. CBT will also work with Purdue University in an evaluation of the use of time constants to predict the part-load performance of central air conditioners.

The Energy Policy and Conservation Act (PL 94-163) requires the Department of Energy to prescribe test procedures for central air conditioners. The Department of Energy published test procedures for central air conditioners in the Federal Register on November 25, 1977. These test procedures were based primarily on tests developed by the Center for Building Technology. DoE is anxious to continue improving and refining these test procedures and has requested CBT to perform this . research. DoE has also asked CBT to submit recommendations on minimum standards for central air conditioners to help meet DoE's responsibilities under the National Energy Act. 


\section{Technical Evaluation Manual for Energy Conservation}

James H. Pielert

(301) 921-3146

Building Economics and Regulatory

Technology Division

Sponsor: Department of Energy

\section{Building Energy Performance Criteria}

Jim L. Heldenbrand

(301) 921-2177

Building Thermal and Service Systems

Division

Sponsor: Department of Energy
CBT's research performed on central air conditioners in FY80 will be aimed at determining if the present test procedure can be simplified. Theoretical work will be carried out on the effect of different indoor/outdoor coil combinations and different design features (thermal expansion device, capillary tube, fixed orifice, etc.) on the part load and seasonal performance of residential central air conditioning equipment. It is hoped that this research will lead to the development of degradation coefficients (or "enhancement factors") that can be assigned in accordance with the different features possessed by a unit. Work will also begin on a central air conditioner computer "model" which could lead to a considerable reduction in the amount of testing required by manufacturers and also make the job of verifying their compliance considerably easier.

The rehabilitation of existing buildings, including energy conservation considerations, requires a knowledge of materials, components, and techniques that frequently differ from those used in new construction. Often, when considering rehabilitation activities to enhance the value and extend the useful life of a building, those involved face a lack of information on technical matters. This work will attempt to fill that gap.

Recent Federal initiatives to regulate energy use at the design stage of new buildings have pushed toward the expansion of performance standards to include the whole building level. Preliminary research for the development of such building energy performance standards (BEPS) was based largely on statistical analysis of calculated building design energy requirements without specific regard to the performance of the building components themselves. A life-cycle costing (LCC) approach to development of BEPS has been recommended by CBT and preliminary work by Battelle N.W. Labs and Lawrence Berkeley Lab for DoE has applied the LCC approach to envelopes of residential buildings. CBT will be developing illustrative building energy performance criteria that cover both the envelope and heating and cooling equipment for single-family dwellings. This project will produce a methodology for integrating component performance criteria which represent user needs into economics-based whole-building criteria. 


\section{Retrofit Training Criteria}

Heinz R. Trechsel

(301) 921-3195

Environmental Design Research Division

Sponsor: Department of Energy

\section{Revision for Bioclimatic Chart}

Preston McNall

(301) 921-3595

Environmental Design Research Division

Sponsor: Department of Energy
This project will support the Residential Conservation Service (RCS) program by developing installation standards and a comprehensive resource document for persons preparing State plans; training programs and manuals for installers, inspectors, and auditors; and informative literature for dissemination to homeowners, occupants, and others involved in the manufacture, marketing, and installation of energy-conserving retrofit measures. The document will also be used by standards organizations as a basis for converting the installation standards to National Voluntary Consensus Standards and by building officials who regulate energy retrofit measures.

The Bioclimatic Comfort Chart, originally published in 1963 , has had exceptionally wide influence on architects and planners involved in climate-adapted architectural design. It is the key element in a comprehensive climatic design procedure. It defines the overheated and underheated times of the year in a given climate and provides for the subsequent design guidelines on the positioning of sunscreens and windows; provision for natural ventilation; placement of thermal mass and insulation; optimal building configuration, aspect ratio, and orientation; and siting and landscaping measures.

The Bioclimatic Chart was, however, based on research performed prior to 1963 , and there has been a great deal of new work since that time that suggests different comfort boundaries. There has also been new research on different age groups, clothing levels, and activity levels other than those included in the present Bioclimatic Chart, which is based on young adult, T-shirt clad, reclining subjects. In addition, there is some information now available on the comfort effects of high intensity asymmetric radiation such as is experienced when sitting in direct sunlight, effects of higher levels of wind motion, and effects of changing thermal conditions. Under this project, the chart will be revised to account for these new developments.

Daylight has been recognized as an effective way of reducing the energy required for illuminating buildings. However, attendant impact on space heating and cooling requirements must be considered. Comprehensive computer programs for calculating natural daylighting are available, which incorporate complex mathematical representations of light-ray reflections from surface to 


\section{Daylighting Prediction Methodology}

Tamami Kusuda

(301) 921.3501

Environmental Design Research Division

Sponsor: National Bureau of Standards

\section{NFC Research Associate Program (Daylighting)}

Tamami Kusuda

(301) 921-3501

Building Thermal and Service Systems

Division

Sponsor: National Fenestration Council surface within a room. Because of the costly machine time, none of the existing building energy analysis programs consider these interreflection simulations. NBS has developed a simplified daylighting calculation routine based upon a two-surface reflection model and intended for use with NBSLD. To validate this simplified procedure, experimental work is required to find a method of correlating the daylighting with the total hemispherical radiation over a horizontal surface. This project will undertake these experiments.

Under this project, an instrumented mobile-home daylight testing laboratory will be used to continue measurement of available indoor daylighting as a function of outdoor solar radiation for many sets of window configurations, internal wall reflectances, and time of day. Also measured will be the air-conditioning energy saved and illumination energy saved as the result of the daylight using various window and room management strategies. Modifications will be made to the cooling system to accurately measure the cooling load of the test room. The results of this work will be used by building reseachers at NBS, LBL, CERL and AIARC for developing energy analysis tools, guidelines, and criteria and standards for energy conservation in buildings. The work will be coordinated with the programs of the IES (Research and Daylighting) and the IERI.

The National Fenestration Council, representing the window manufacturers, and skylight and glass industries, is interested in developing the energy conservation features of window design and window operation. Windows can be made very effective by the proper use of daylighting as a means of reducing electric lighting loads while also benefiting from solar heat gains. But to truly understand the energy implications of daylighting designs, a dynamic computer simulation is necessary, one capable of analyzing hourly daylight and thermal conditions. This project, once completed, will permit various energy analysis procedures such as DOE-2, BLAST, and NBSLD to include well-validated daylighting calculations. This work will be carried out under the memorandum of agreement between the NFC and the National Bureau of Standards. A research associate was identified by NFC to work with CBT in carrying out the technical activities for 2 years. Mr. Gary Gillette is working with CBT architects and engineers using CBT's daylight research facilities. 


\section{Life-Cycle Cost Methodology}

Rosalie T. Ruegg

(301) 921-2330

Building Economics and Regulatory

Technology Division

Sponsor: Department of Energy

\section{Cost-Effectiveness of Infrared Heat- Loss Surveys (Ground-Based)}

Richard A. Grot

(301) 921-3470

Building Thermal and Service Systems

Division

Sponsor: Department of Energy

Infrared Aerial Survey Evaluation

Douglas M. Burch

(301) 921.3602

Building Thermal and Service Systems

Division

Sponsor: Department of Energy
The report Life-Cycle Costing Manual for the Federal Energy Management and Planning Programs will be revised and published in accordance with final LCC Rules, the revised energy price projections of EIA, and comments and suggestions from reviewers. A series of nine regional Federal Life-Cycle Costing Workshops has been conducted to instruct managers of Federal facilities and others about the new life-cycle costing rules. A publication on life-cycle costing for the private sector will be prepared. The publication will be consistent with the NBS BSS113 report, Life-Cycle Costing-A Guide for Selecting Energy Conservation Projects for Public Buildings, and will extend the life-cycle costing procedures to incorporate taxes and other evaluations of energy conservation investments in the private sector.

Although thermal surveys of buildings are considered to be highly efficient from a technical viewpoint, they are much more expensive than traditional inspection methods. The traditional methods, however, are less reliable. This project will correlate the energy savings, costs, and techniques of infrared scanning to calculate the most effective way of doing such surveys in urban residential areas. The surveys will be carried out by contractors in 10 cities. The results will be submitted to the ASHRAE committee on standards for thermographic inspections.

Considerable controversy exists within the technical community concerning the effectiveness of aerial IR surveys in rating the insulation levels of peaked residential attics. Proponents of these surveys argue that buildings which are losing comparatively more heat through the ceiling will have warmer roofs, causing them to appear as having higher apparent radiation temperatures than buildings with better insulated attics. Others argue that the apparent radiance temperature of a roof is dependent upon too many factors, such as roof emittance, local air temperature, and wind speed, to enable the aerial scans to directly provide accurate information.

Analysis of the "halo" surrounding the image of a house in an aerial thermogram has been suggested as a procedure for identifying the level of wall insulation and to check for storm windows. If validated, this procedure would allow complete examination of the exterior envelope of a residence from the air, reducing per-house cost and time required for energy auditing. Under this project, a field study will be performed using three sideby-side houses (located in Springfield, Mo.) as test structures. Insulation levels and storm windows would be varied to allow side-by-side comparisons of the aerial 
thermograms. The investigation would be performed as a joint effort between CBT, Texas Instruments, and Energy Measures Corporation.

\section{Weatherization Demonstration}

Richard Crenshaw

(301) 921.2019

Environmental Design Research Division

Sponsor: Community Services

Administration
The objectives of this project are to develop a field method for evaluating combinations of energy conserving options, to measure the energy and cost savings associated with these options, and to develop installation standards to assure consistent performance of the options when installed.

A sample of 300 frame, masonry, and masonry veneer, one-and two-story houses have been selected in 16 cities across the United States. More than 200 of these houses were weatherized with both architectural and mechanical energy conserving options. The effectiveness of the package of options selected for each site will be evaluated by carefully comparing actual installation costs with field measured savings. Houses which show unusually high or low savings will be further evaluated using diagnostic tests to explain the variations.

The results provide CSA with a quantified basis for their weatherization program. The results will also provide a field check on the accuracy of ASHRAE and other current energy calculation procedures for residences, leading to suggestions for improving calculations used in predicting energy performance.

Reduction of outside air is one of the strategies proposed to save energy in the heating and cooling of buildings. There is need for better information on natural ventilation rates of buildings with outside air dampers closed. High-rise buildings present special problems. Such information is needed before we know where we stand with respect to existing ventilation standards, as well as the possible revision of standards. Under this project, the NBS Administration Building has been instrumented to measure air exchange by using $\mathrm{SF}_{6}$ tracer gas.

In addition to selected tracer gas measurements, the current fan pressurization system will be finalized and experience will be gained in the logistics of large building measurements. If successful, flow parameters will be measured for whole buildings and sub-elements such as floors and rooms, and these will be used in simulation models. The measured data will be compared with those calculated by the comprehensive multi-room air leakage model. A preliminary test of the Shaw-Tamura model has been carried out and will be reported. First generation results suggest that more attention should be given to the effects of the mechanical ventilation systems and exhausts. 


\section{Guidelines for Controlling Attic Condensation}

Douglas M. Burch

(301) 921-3620

Building Thermal and Service Systems

Division

Sponsor: Department of Energy

\section{Modeling Cooling with Whole-House Fans}

Douglas M. Burch

(301) 921-3620

Building Thermal and Service Systems

Division

Sponsor: National Bureau of Standards
Insufficient attic ventilation may lead to condensation on the underside of roof sheathing of residential buildings. Current guidelines on the minimum amount of attic ventilation are based on the experience and knowledge of persons in the building industry; they were developed approximately 30 years ago when the ceilings of houses had very limited insulation. Due to the energy shortage, current recommendations require much greater amounts of ceiling insulation. Houses with heavily insulated ceilings will have colder attics, which will be more susceptible to condensation and require higher ventilation rates. A strong need exists to establish a rigorous rationale for formulating guidelines for controlling attic condensation. This project will also resolve the issue as to whether a ceiling vapor barrier should be required.

A typical home air conditioner may require five times as much energy as a fan. The NBS studies in 1977 at the Houston attic ventilation test houses confirmed that in many regions, outside air during the cooling season fulfills comfort conditions during most of the year. It would be desirable to capitalize on fan cooling and determine how much energy could be saved and what kind of indoor environment can be expected under cooling with forced ventilation.

This project is to determine more precisely when outside air may be substituted for air conditioning, what ventilation rates are required, how much energy is saved, and algorithms to simulate the effects of forced ventilation under different ventilation schedules and different climates.

Although underground heat distribution systems are often considered in the energy conservation plans of communities, many of the existing systems have been failing due to ground water seeping into the system and the rupture of the carrier pipes. Under this project, CBT has constructed a conduit boiling test apparatus, conducted the boiling tests on three different calcium silicate insulation systems, and prepared three technical reports. The Tri-Services engineers are interested in noncalcium silicate-type insulation for the conduit boiling test as well. 


\section{Energy Conservation Through Waste Use in Cement and Concrete}

James R. Clifton

(301) 921.2630

Structures and Materials Division

Sponsor: Department of Energy
The manufacture of portland cement consumes about 2 percent of the energy consumed in U.S. industrial processes. As much as 20 percent of the energy consumed by the cement industry could be conserved by the use of waste materials in cements and concretes. CBT is comparing the behavior of blended cements and concretes containing fly ashes and blast furnace slags to those of portland cements and portland cement concretes to develop relationships between composition, microstructure, and performance. These relationships will form the basis for developing performance-based standards for blended cements, and for fly ashes and slags which are added to concretes.

Criteria will be prepared for tests to determine the sulfate resistance of cements and the effect of fly ashes on chemical admixtures. Also, criteria will be developed on the dimensional stability of blended cements.

CBT is participating in ASTM committees concerned with cements (C1) and waste material (E38). Through this participation, we are playing an active role in the establishment of new performance tests and criteria for blended cements and concretes, and for broadened use of waste materials in construction. 

Builfing Thermal Envelope Systems จก0 Insuाanting Materia|s

\section{Building Thermal Envelope Systems and Insulating Materials}

Budiling Thernal Envelope Systenns

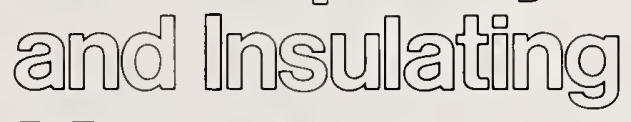
Materia|s

Butiding thernal Envelope Systems

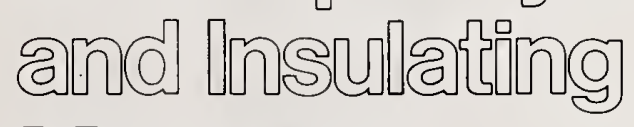
Materia|s

Butilling Them Envelope Systens and Insulanting Materia|s 


\section{Thermal Insulation Standard Reference Material}

Chock I. Siu

(301) 921-3536

Building Thermal and Service Systems

Division

Sponsor: National Bureau of Standards

\section{Thermal Insulation Analysis}

\section{Brian Rennex}

(301) $921-3637$

Building Thermal and Service Systems

Division

Sponsor: National Bureau of Standards

\section{Thermal Insulation Test Series}

\section{Chock I. Siu}

(301) 921-3536

Building Thermal and Service Systems

Division

Sponsor: National Bureau of Standards
Thermal insulation Standard Reference Materials (SRM) are materials that can be used to calibrate thermal testing devices of industry and independent testing laboratories. Candidate materials, available from economical sources under special order, are measured, characterized, and certified as SRM's. A stock of high-density fiberglass boards has been certified as SRM 1450. Also, density and thermal conductivity measurements have been made on a stock of low-density fiberglass batts for use in the National Voluntary Laboratory Accreditation Program. Measurements and analysis of this low-density material will continue, leading to its certification as a SRM.

Under this project, a base will be established for a multiyear approach to investigations into steady-state and dynamic characteristics of heat, air, and moisture transmission in materials, composites, and building envelope systems. Initial emphasis will be given to a detailed plan to analyze and report on the performance of the new 1000-mm line-heat-source guarded hot plate and to derive and validate formulas and analytical models for thick, low-density insulation. Data being supplied from the Thick Insulation Test Series will be used in this analysis and in the production of reports and papers for publication.

A series of tests is being made on low-density and highdensity fiberglass insulation using the 200-mm guarded hot plate, the $300-\mathrm{mm}$ guarded hot plate, and the new (under construction) 1000-mm line-heat-source guarded hot-plate thick insulation tester. The data from this test series will be used to validate theoretical models and to establish the $1000-\mathrm{mm}$ tester as a suitable apparatus for characterizing standard reference material (SRM) using thick specimens. The technical and economic benefits to the insulation and building industries will be realized by the elimination of present uncertainty regarding effective thermal conductivity of thick low-density materials.

Under this project, new technical data and test equipment and procedures will be developed for design purposes and for standards on the thermal performance of insulating materials and large building elements. The goal will be to reduce energy requirements of buildings while retaining acceptable levels of functional effectiveness, durability, safety, and cost. The project will be carried out as a part of a comprehensive plan developed in cooperation with the Department of Energy, Oak Ridge National Laboratory, the Lawrence Berkeley Laboratory, and the building industry. The results from this activity will be greater and more 
predictable energy conservation, a sound basis for competition in the building industry, and greater assurance of building durability, habitability, and economy to the consumer.

\section{Modeling Mass Effects with Outside Insulation}

Douglas M. Burch

(301) 921-3620

Building Thermal and Service Systems

Division

Sponsor: National Bureau of Standards

\section{Experimental Evaluation of Thermal Mass}

Douglas M. Burch

(301) $921-3620$

Building Thermal and Service Systems

Division

Sponsor: Department of Housing and Urban Development
This study is addressed to the national concern for building energy conservation with specific reference to thermal mass. The present standards, such as ASHRAE Standard 90-75R, DoE Model Code (NCSBCS), and the HUD Minimum Property Standards have not considered building thermal mass. As a result, there is a need to experimentally evaluate the energy savings attributable to thermal mass in building walls, especially with respect to the location of insulation. It costs more to bring masonrywall buildings up to existing heat-loss standards than stud-wall buildings. The masonry-wall industry has sought relief from these standards through recognition of a thermal storage effect. A congressional subcommittee recently passed a resolution to block the latest HUD MPS revisions until thermal mass is recognized. The results of this study and related efforts will give HUD, FmHA, and DoE a needed technical base for policy decisions.

This project addresses the concern for building energy conservation, and specifically, thermal design of building envelopes. The present standards, such as ASHRAE 9075R, DOE Model Code (NBSBCS), and the HUD Minimum Property Standards, emphasize building insulation without due regard to building thermal mass. CBT will experimentally evaluate the energy savings from thermal mass in residential walls. Based on the results of this work, preliminary guidelines for reduction in thermal resistance for energy conservation standards will be developed as a function of climate, orientation, type of wall construction, and mode of operation for the building. Five one-room test structures will be constructed outdoors at the NBS site. These test structures will have the same floor plan, orientation, and other common features. The walls of these structures will be (1) insulated lightweight wood frame, (2) uninsulated lightweight wood frame, (3) insulated masonry, (4) uninsulated masonry, and (5) log. The experimental plan is to instrument these test structures for measuring wall heat transmission, heating and cooling energy requirement, rate of air infiltration, and indoor comfort condition. The test structures will be exposed to outdoor conditions for one calendar year. Differences in wall heat transmission, heating and cooling energy requirements, and indoor comfort attributed to variations in wall thermal mass will be quantified and correlated with respect to the outdoor climatic condition. The NBSLD 
Computer Program will be validated for predicting these parameters for a full range of outdoor conditions.

MIMA Research Associate Program

Robert R. Jones

(301) 921-3636

Building Thermal and Service Systems

Division

Sponsor: Mineral Insulation Manufacturer Association
The Mineral Insulation Manufacturer Association is interested in developing testing procedures for accurate determination of the thermal resistance of thick insulation. An essential element in this development is the construction of and initiation of tests on a new line-heatsource guarded-hot-plate thick insulation tester at NBS. Another element is the development of mathematical models and an analysis program to use test data to be generated on the new tester. These activities will lead to the capability of delivery to private testing laboratories of thick insulation transfer calibration specimens. A research associate, selected by the Mineral Insulation Manufacturer Association, will work with CBT for 2 years in this effort.

Increasing national interest in energy conservation encourages the use of thick insulation-sometimes as much as $300 \mathrm{~mm}$ (12 in) or more. The existing NBS apparatus is only capable of accurate thermalconductivity measurements of insulating material specimens up to $50 \mathrm{~mm}$ thickness. An apparatus capable of precise measurements of thick insulation is urgently needed to provide a calibration base for industry and for independent testing laboratories. This project will result in construction of a 1000-mm diameter line-heat-source guarded-hot-plate apparatus for thermal conductivity measurements on materials up to $350-\mathrm{mm}$ thick.

This year, the construction of the calibrated hot box for testing large wall sections will be started. It will be capable of simultaneous testing of air, moisture, and heat transfer through test walls $3 \mathrm{~m} \times 5 \mathrm{~m}$ in size, subject to diurnal environmental chamber cycles. A test program will be prepared and a draft standard calibration procedure and error analysis will be developed.

Long-term laboratory tests, started in FY79 to evaluate the durability of electrical boxes in an insulated environment, will be continued. Additional sealed humidity-controlled vessels containing outlet boxes and switch boxes (including wiring devices) with and without thermal insulation will be included in the test program. These tests will use new thermal insulation samples that satisfy the proposed HH-I-515D corrosion specification. Test results will be compared with "idealized" testing 
results from 515D. Additional tests will attempt a correlation of corrosion on other building elements, such as piping and nails, that come in contact with the thermal insulation.

\section{Retrofit Criteria: Insulation and Wiring}

Lawrence S. Galowin

(301) 921-3293

Building Thermal and Service Systems

Division

Sponsor: Department of Energy
This project will conduct laboratory tests of several insulation materials to establish tables of allowable thermal blanketing over wiring of various sizes at their peak ampacity ratings. Acceptable installation practices to provide thermal release paths for thermal insulation will be determined. CBT will also study the ability of studs, joists, and gypsum to reduce wire temperatures. The outcome of this work will be safety criteria for use by DoE. 

Builong So|(2)

Systems

Technology

\section{Building Solar \\ Systems \\ Technology}

Builong Soldar

Systenns

Technology

Bualling Solar"

Systems

Techno|logy

Bundong Solar"

Systems

Technology

Bualding Solar"

Systems

Technology 


\section{Collector Durability and Reliability Test Program}

David Waksman

(301) 921.3285

Building Economics and Regulatory

Technology Division

Sponsor: Department of Energy

Standards for Rubber Hose and Connections

\author{
Robert D. Stiehler
}

(301) 921-3180

Structures and Materials Division

Sponsor: Department of Energy
The reliability and long-term performance of solar collectors has not generally been demonstrated. Recent studies have indicated that significant changes in collector performance (greater than 10 percent) can occur as a result of exposure to "no-flow" conditions for 3 to 9 weeks. Various component and materials tests have been proposed to evaluate the reliability/durability of solar collectors. However, these testing procedures have to be proved. This project is intended to provide a coordinated testing program that will result in establishing validated testing procedures to relate laboratory, accelerated field, simulated operational exposure, and actual field demonstration data for solar collectors used in building heating and cooling applications.

A review of existing and planned testing procedures useful in evaluating the reliability/durability of collector units and their materials will be conducted. Laboratory and outdoor field exposure tests will be performed on solar collectors and their materials. The results of these tests will be correlated and compared with actual in-use performance. Long-term field exposures will be conducted at a number of different sites to evaluate climatic effects. Test specimens representative of various collector types are being used.

Rubber hose is an economical and efficient connector between the solar collectors and manifolds on the supply and return lines of solar energy systems. Rubber hose is sometimes also used at the inlet and outlet of pumps, storage tanks, and other components in the system. At present, however, there is no standard for hose used in solar systems. The environment and other conditions surrounding solar energy systems necessitate a highquality hose with a long life, good resistance to ozone and other atmospheric pollutants, and good performance at high and low temperatures. Standard methods of testing hose for most of these characteristics are given in ASTM D380-77. The principal task here is to establish minimum requirements for the hose, based on these tests, to assure satisfactory performance in solar energy systems.

The approach will consist of identifying performance requirements, important properties related to performance, factors that could affect the performance, and existing tests to measure performance of rubber hoses and connections. Laboratory studies will be performed to determine if materials meet the requirements and to develop procedures, as needed, to measure performance. Based on the laboratory studies, draft standards will be submitted to ASTM Committee D11 for consideration as consensus standards. A report, Solar Energy SystemsStandards for Rubber Hose (NBSIR 79-1917), which 
presents results of laboratory studies and a recommended draft standard, was published in November 1979.

\section{Standards for Solar Cover Plates}

Elizabeth J. Clark

(301) 921.2635

Structures and Materials Division

Sponsor: Department of Energy
Most solar collector designs incorporate a cover plate whose purpose is to transmit solar energy while protecting the inner areas of the collector from the exterior environment and reducing the heat loss. Any loss in the transmittance of solar energy through the cover plate results in a decrease in the efficiency of the entire solar heating and cooling system. The transmittance and other important properties of some cover plate materials are frequently deteriorated by sunlight and the temperatures encountered in solar collectors. Many standard test methods are available to evaluate materials such as glass and plastic. However, the performance requirements for cover plates of solar collectors are not entirely covered by the existing test methods. The purpose of this project is to prepare draft performance standards for cover plate materials used in flat-plate solar collectors. The products of the project, drafts of standard test methods by which cover plates used in solar energy systems may be evaluated, will be sumitted to ASTM Committee E44 for consideration as consensus standards.

Materials used to contain, transport, or store fluids in solar energy systems are called containment materials. Plastic containment materials are being used increasingly in solar collectors, solar ponds, tanks containing heated storage liquids, and piping. Numerous field problems have been reported with plastics. These problems stem primarily from the poor thermal and UV stability of some plastic materials. Many standard methods are available to evaluate plastic materials. However, the performance requirements for containment materials in solar systems are not entirely covered by the existing test methods. The purpose of this project is to prepare draft standards for nonmetallic containment materials used in solar systems. Initially, performance criteria, performance attributes, degradation factors, and currently available tests were identified. Tests were then assessed to determine if modifications were necessary to reflect solar conditions in use. Laboratory and field studies are being performed to obtain data needed to prepare testing standards. Draft standards will be submitted to ASTM Committee E44 as possible consensus standards. 


\section{Standards for Solar Absorptive Coatings}

Larry W. Masters

(301) $921-3458$

Structures and Materials Division

Sponsor: Department of Energy

\section{Evaluation of IPC Corrosion Test Methodology}

Paul W. Brown

(301) 921-2993

Structures and Materials Division

Sponsor: Department of Energy

\section{Solar Hot Water System Test Program}

\author{
Arthur H. Fanney \\ (301) 921-3754 \\ Building Thermal and Service Systems \\ Division
}

Sponsor: Department of Energy
While numerous standard tests have been developed for coatings in building construction, the performance requirements involved in solar systems are quite different. For example, temperatures on the absorptive surface may reach $250^{\circ} \mathrm{C}$ or greater, but standard test methods for coatings seldom involve temperatures as high as $100^{\circ} \mathrm{C}$. The purpose of this project is to prepare such draft standards, which will be based upon results of laboratory and field studies and will be submitted to the ASTM Committee E44 for consideration as consensus standards. ASTM acceptance is expected by the end of 1980. The research findings will ensure improved absorptive coatings performance, provide a basis for selecting proper materials, and enhance acceptance of solar systems by making them more reliable.

This project will assist in the selection of proper metalfluid pairs as a basis for the design of durable solar collector systems. Currently there are no technical data to ensure the validity of the corrosion test methodology as described in Interim Performance Criteria, NBSIR 76 1187, November 1976 (IPC).

Under this project, two simultaneous experiments are being conducted. In the first, six representative domestic hot water systems, with water-heating and air-heating collectors, single and double tank configurations (with and without heat exchanger), and with pumped and thermosyphon flow, are being subjected to controlled field tests for 12 months. In the second experiment, controlled laboratory tests are being run on selected components with simulated solar input to examine the effects of stratification and heat exchangers on system performance as well as to examine alternate methods of testing complete systems in the laboratory.

Reports and technical papers comparing experimental data with the performance predicted by the applicable computer simulation codes for the six field-installed systems for the first 12 months (July 1978-June 1979), and a description of the changes and additions made to the test facility for FY 80 have been published. Reports and technical papers covering the test results for the second 12 months will also be published. Results on the laboratory verification of the recommended test procedure for rating solar domestic hot water systems under consideration by ASHRAE (Standard 95P) will be published. 


\section{Structural Performance of Solar Collectors}

Emil Simiu

(301) 921-2346

Structures and Materials Division

Sponsor: Department of Energy

\section{Thermal Test Methods for Solar Collectors}

Elmer R. Streed

(301) 921-3285

Building Thermal and Service Systems

Division

Sponsor: Department of Energy
In designing solar collectors and their supports, the effects of aerodynamic loads induced by wind, snow loads caused by drifting and accumulation around the collectors, loads induced by seismic events, loads associated with incompatible thermal expansion of collector arrays, and the resistance of collector systems or elements to the action of hail, must be considered. For certain collector systems the technical information required for safe and economical structural design is not available. The purpose of this project is to develop structural performance criteria and guidelines, especially for collector supports and fasteners. The results of the research will be used by designers and code writers.

Standardized testing and rating procedures for solar collectors are needed in a form similar to those published for fuel-burning equipment, air conditioners, and heat pumps. Many different kinds of solar collectors are being developed at universities and research laboratories and there is an urgent need to compare their performance on some common basis. In addition, commercial models of various collectors are now available and the procedures provide an equitable basis for competition among manufacturers and an essential basis for design and selection of equipment. So far, under this project, standardized testing procedures for solar collectors have been proposed and adopted. Test facilities incorporating three test stands for conducting indoor and outdoor tests of solar collectors have been constructed at CBT. The procedures will be investigated, verified, and modified.

Although passive systems exist and are growing in number, quantitative thermal performance data are lacking, and a quantitative comparison with another passively or actively heated and cooled building is difficult. The first step in this project has been to write a reference document that identifies a systematic classification, recommends measurements, performance reporting, and data analysis techniques to be used in experimental invesitgations of passive solar heated buildings. To assess the validity and usefulness of the reference document it will be applied to the evaluation of instrumented passive buildings. Since there is a lack of instrumented passive solar buildings in regions other than the South and West, one building will be built at the NBS site in Gaithersburg, and will consist of four tworoom test units that incorporate the major passive concepts described in the reference document. 


\section{Economic Evaluation of Passive Solar Designs for Urban Environments}

Jeanne Powell

(301) 921-2330

Building Economics and Regulatory

Technology Division

Sponsor: Department of Energy

Installation of Solar Components on Roofs

Robert G. Mathey

(301) 921.2629

Structures and Materials Division

Sponsor: Department of Energy

\section{Solar Evaluation of the Norris Cotton Building}

William B. May

(301) 921-3754

Building Thermal and Service Systems

Division

Sponsor: Department of Energy
This project is aimed at increasing the application of solar designs in cities by developing evaluation methods, cataloging systems and materials, conceptualizing prototype solar applications, developing guidelines for their use, and estimating the energy benefits and lifecycle costs of the prototypes. The method will focus on the costs of purchase, installation, maintenance, repairs, replacement, and energy and will include a number of more difficult-to-measure benefits and costs, such as the effects of passive solar design on resale value of the building, lighting, building income, and space availability and use for agriculture and other commercial activities.

A final report will be published in 1980 .

Solar components have been installed on commercial/industrial type buildings without regard to their effect on the roofing systems. Improper applications have led to ponding of water on the roof, leakage, moisture build-up, deterioration of the roofing system, and inadequate slope to drain. In this project, technical data will be developed on the proper installation of solar components. This will include the investigation of roofing problems attributed to solar components installed on roofs and the definition of problems, determination of their causes, and recommended solutions. Guidelines will be prepared for proper solar component installation with regard to roof maintenance, repair, retrofitting, and replacement. Consideration eration will be given to building collector panels into roof systems instead of placing them on elevated supports.

A solar energy system has been integrated into the heating and cooling systems of a Federal office building in Manchester, N.H. This building was specifically constructed to demonstrate energy conservation features for commercial buildings. Under this project, tests of individual solar panels in this system will be made to compare collector performance with the requirements in the original contract specifications. Performance data will be gathered on a long- and short-term basis by an automated data system. The contribution of the solar system toward reducing fossil fuel requirements will be determined. Quarterly reports on the performance of the system as measured at the building will be produced. 


\section{Monitoring Methods for Low-Cost Residential Solar Systems}

Elmer R. Streed

(301) 921-3285

Building Thermal and Service Systems

Division

Sponsor: Department of Housing and Urban Development

\section{Commercial Solar Energy Demonstration}

Robert D. Dikkers

(301) 921-3285

Building Economics and Regulatory

Technology Division

Sponsor: Department of Energy

\section{Solar Energy Program for Housing Systems}

Robert D. Dikkers

(301) 921.3285

Building Economics and Regulatory

Technology Division

Sponsor: Department of Housing and Urban Development
The successful large-scale use of solar energy for residential space or domestic hot water heating is predicated on proper operation of the solar system, without the use of sophisticated monitoring apparatus. Experience obtained by HUD in the Solar Demonstration Program and by others has indicated the performance of noninstrumented installations can vary significantly from one unit to another because of undetected operational problems. One method of minimizing the effect of these problems is to provide the operator with a set of systems capable of detecting improper operation. Under this project, three levels of instrumentation, ranging from meters to onsite minicomputers, will be installed in the CBT solar townhouse. This instrumentation will be evaluated for ease of installation, operation, range, accuracy, cost, and appropriateness.

CBT staff members have participated in the preparation of draft standards and performance criteria and have participated in the evaluation of commercial solar system performance. Experience gained from the evaluation of system performance will be fed back into the development of improved criteria. During FY80, CBT staff will seek comments and suggestions on existing performance criteria (NBSIR 76-1187, Interim Performance Criteria for Solar Heating and Cooling Systems in Commercial Buildings) from industry, designers, and other members of the building community. In regard to standards development, CBT staff will work with appropriate ANSI, ASME, ASHRAE, and ASTM committees. CBT will also assist DoE in the evaluation of flat-plate collector test results obtained in a DoE Interim Collector Testing Program.

Under this project, an interdisciplinary team of CBT staff members has participated in the preparation of intermediate solar standards and performance criteria and is participating in the evaluation of residential demonstration solar system performance. Experience gained from the evaluation of system performance will be fed back into the development of improved criteria. The evaluation process during the demonstration program will involve comparisons of actual with predicted system and component thermal performance, and the evaluation of operational problems (materials degradation, equipment failures, etc.). 


\section{Dimensional Considerations in Solar Installation}

Hans J. Milton

(301) 921-2720

Building Economics and Regulatory

Technology Division

Sponsor: Department of Energy

Solar Federal Buildings Program

Robert D. Dikkers

(301) 921-3285

Building Economics and Regulatory

Technology Division

Sponsor: Department of Energy
The sizing of collectors, reticulation networks, and storage units in active solar systems-including their dimensional relationships and tolerances-has not so far been subject to any standardization except for domestic hot water tanks. An awareness of dimensional and sizing considerations is important to the development of preferred unit and connection sizes. In addition, the implications of the likely change to metric units and dimensional coordination in building during the 1980's represents a challenge to the solar industry, since many of the system components are derived from the building materials supply sector.

The major thrust of this study will be to identify dimensional considerations and to illustrate their impact on solar systems, especially external components. The determination of preferred sizes will allow greater interchangeability, standardization, and performance comparison of dimensionally similar units. A report will detail existing dimensions in the industry and provide a starting point for the development of preferred dimensions. It will also indicate areas requiring further study or development.

Under this task, CBT will provide consulting and advisory services to support the. DoE Solar Federal Buildings Program. These services will include the following: active participation in DoE and SERI conferences to discuss performance criteria and standards; assistance in the development of plans to collect various data (i.e., maintenance and operational data); and assistance, as in establishing a computer data base to process and evaluate informaton collected from Federal agencies participating in the DoE program.

A large-scale effort is scheduled for using solar energy systems in new and existing Federal buildings. The efficient implementation tation of the program by the many Federal agencies involved can be greatly aided by the development and use of model performance oriented specifications for the systems to be purchased.

CBT will compile specifications now being used by Federal agencies for purchasing solar heating and cooling systems. The analyzed data, augmented by recent solar research findings, will be used to develop a model set of purchase specifications for each system category. Drafts of these models will be reviewed by technical representatives of designers, manufacturers, and Federal agencies. The resulting model purchase specifications, revised in line with the review committee comments, will be published in a final report. 


\section{Economic Optimization Guide for Solar Systems in Federal Buildings}

Rosalie T. Ruegg

(301) $921-2330$

Building Economics and Regulatory

Technology Division

Sponsor: Department of Energy
To obtain cost-effective solar systems, it is important that economic evaluations be used in their early planning, design, and sizing. Although a number of computer programs are currently available containing economic evaluation subroutines, they are generally "black-box" algorithms that are part of larger thermal analysis programs. These programs afford the user little understanding of the optimization procedure. Furthermore, there is often wide variation in the economic results obtained by using such programs. Under this project, a solar optimization guidebook will be developed that will explain the optimization procedure, provide a model and accompanying interactive computer program, give examples illustrating the use of the program, and be accompanied by a computer software package consisting of both computer cards and magnetic tape.

It is clear that those groups involved with building rehabilitation lack the information on matters required to make the best technical decisions. This is especially true in the area of solar retrofit since most building systems (structure, electrical, plumbing, mechanical) would be affected. This project will attempt to fill this informational gap by developing a methodology and body of technical data for evaluating the condition of existing building systems.

CBT has a major role in the preparation of performance criteria and test methods for the use of solar energy in the United States. DoE has requested that this expertise be used to contribute to the formulation and evaluation of solar collector testing procedures being developed by various countries participating in an International Energy Agency (IEA) Working Group. This project will foster the development of IEA-recommended test procedures by participating in international critiques of U.S. and foreign standards and proposed test procedures and by taking part in round-robin thermal performance and durability tests of various collectors.

The National Program for Solar Heating and Cooling is aimed at helping alleviate a critical shortage in the Nation's available fossil fuel resources by promoting widespread commercialization and accelerated use of solar heating and cooling. The raw (noninstrumental) data that is collected from the HUD residential demonstration program is stored, processed, and transmitted to appropriate users and contractors for additional study, evaluation, and dissemination. Such a system is currently in operation, and feedback from the

Sponsor: Department of Housing and Urban Development 


\section{Development of Solar Regulatory Provisions}

\author{
Joseph Greenberg \\ (301) 921.2758 \\ Building Economics and Regulatory \\ Technology Division
}

Sponsor: Department of Energy

\section{Code Analysis of Thermal Energy Storage}

\author{
Joseph Greenberg \\ (301) 921-2758 \\ Building Economics and Regulatory \\ Technology Division
}

Sponsor: Department of Energy users has indicated a need for a more complex design. In 1979 , the new design was implemented, new user documentation written, and training sessions given. Two reports describing the data center and available computer reports were published in 1979 (NBSIR 79-1762 and NBSIR 79-1923) Residential Solar Data Center Data Resources and Reports and Residential Solar Data Center Grant Reports. InFY80, emphasis will be placed on developing special reports of summary data to be used for analysis of trends and problem areas.

To make solar energy a viable and maturing energy source for the Nation, the regulatory system must not impede technical development. Under NBS leadership, a solar regulatory study was conducted and published in 1978. Using the NBS study as a base, this project is currently assisting DoE in the development of model solar building regulatory provisions in a consensus mode under the sponsorship of the Council of American Building Officials, using the ANSI-accredited organization approach.

Thermal energy storage systems may possess characteristics which are inherently hazardous to health and safety unless proper precautions are exercised. Local building officials, charged with the responsibility for overseeing and enforcing the health and safety provisions of the various building codes, must be satisfied that solar components and systems proposed for installation comply with accepted guidelines established for their jurisdictions.

CBT will study the thermal energy storage/code and standards interface. Thermal energy storage systems and components will be reviewed and potential hazards to health and safety identified and discussed with the hardware and system developers. These potential hazards will be assessed in relation to existing code provisions and a determination made regarding the potential acceptance of this equipment by code enforcement officials. The code changes needed to allow installation of equipment in an unmodified configuration will be identified and a course of action suggested.

The four nationally recognized model codes (Basic, Standard, Uniform, and National), their associated plumbing, electrical, mechanical, and life safety codes, and other applicable documents will be reviewed to determine those provisions which would restrict or prohibit the installation and use of thermal energy storage devices. 


\section{Solar Utilization in Cities and Towns}

S. Robert Hastings

(301) 921.2107

Environmental Design Research Division

Sponsor: Department of Energy
Heating buildings accounts for about one-sixth of the Nation's energy consumption. Solar energy is acknowledged as a logical source for this heat and its use is increasingly common in rural and suburban areas. More widespread use of solar energy in urban settings has not occurred because of physical, social, political, and economic barriers. This project will analyze these barriers and recommend technical options for enlarging the use of solar energy in cities. Current evaluation techniques are largely inadequate for assessing the solar and thermal performance of the large-scale passive solar designs that show greatest promise for reducing energy consumption in such urban surroundings. Without adequate prediction ability, it will be impossible to confidently install demonstration projects or evaluate the nature of their effectiveness. There is, therefore, a need for an evaluation procedure that assesses the thermal and economic performance of large-scale and multi-building passive solar applications. At the same time, there is a need for thermal and economic results calculated by such a procedure on a selected range of prototype retrofit techniques.

In conjunction with the Center for Electronics and Electrical Engineering, CBT is providing consulting and review support to the Solar Energy Research Institute for the development of performance criteria and test methods for the use of photovoltaic and combined photovoltaic/thermal (PV/T) systems in buildings and other applications. CBT staff participates in group meetings related to the development of performance criteria and standards. Indepth reviews of draft documents are made and new requirements for test methods are identified. Proposals for the development of new test methods or studies are prepared. 



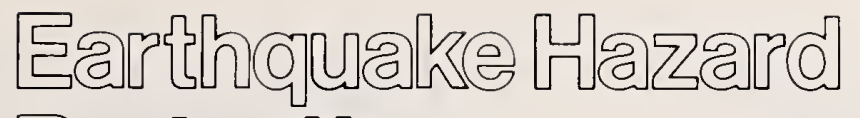

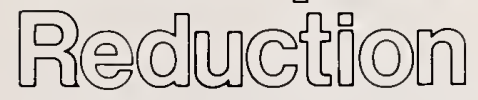

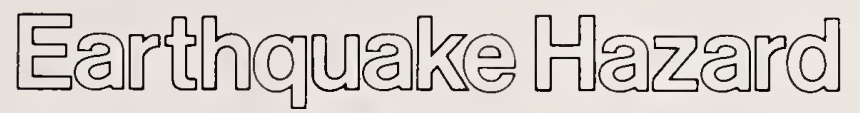

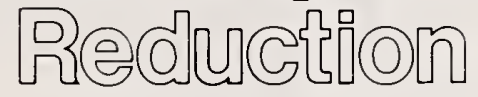

\section{Earthquake Hazard Reduction}

[Eจ

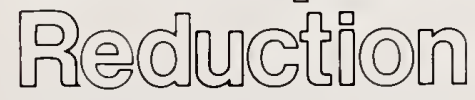

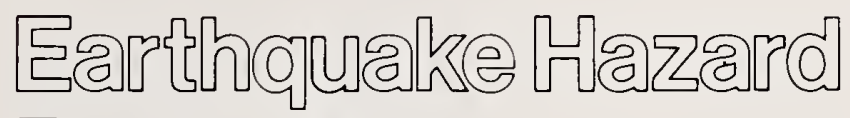
Reducton

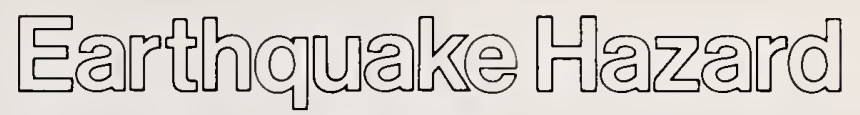
Redustion

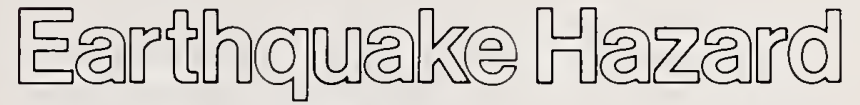
Reduction

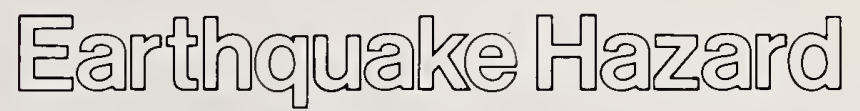
Reduston

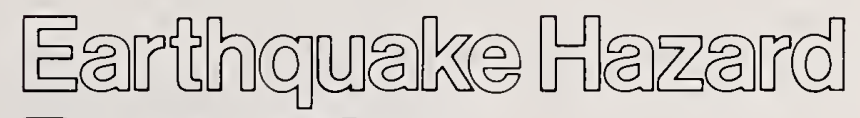
Reducton 


\section{Characterization of Structural Response to Earthquakes}

\section{Edgar V. Leyendecker \\ (301) $921-3471$}

Structures and Materials Division

Sponsor: National Bureau of Standards
During the development of tentative design provisions for buildings, information on strength-based design criteria for structures, particularly reinforced mansonry, was found to be incomplete. New analytical approaches, confirmed by laboratory test data, are required. This project will investigate the dynamic behavior of structures and components to determine performance characteristics up to the ultimate limit state and provide a basis for the formulation and validation of methods of analysis and design.

Analytical and laboratory work will be directed initially towards developing masonry shearwall design guidelines. These guidelines will be based on research conducted at various research laboratories, including NBS. Laboratory research will include cyclic testing on masonry shearwalls, primarily lightly reinforced, with some heavily reinforced for correlation with research conducted elsewhere.

In 1974 the National Science Foundation and the National Bureau of Standards initiated a program to develop improved seismic design provisions for buildings. As a consequence, the "Tentative Provisions for the Development of Seismic Regulations for Buildings" were developed by the Applied Technology Council in an effort that included a wide range of experts in the actual drafting of the provisions. Two external review drafts were circulated to a large portion of the interested and informed community of eventual users. However, because the Tentative Provisions are quite innovative, serious doubts about them may exist. Prior to undertaking an expensive assessment of the Tentative Provisions through trial designs, an attempt will be made to investigate these doubts and to improve the provisions where possible. It is likely that many issues exist that will not be resolved by this activity; some will require the information that will be developed in the conduct of the trial designs and subsequent impact assessment before resolution can be expected.

This project will improve the agreement among concerned parties on the technical details of the Tentative Provisions. This will be done through a series of technical committees that will be assembled to resolve comments on the structural design requirements and design procedures, resolve comments on the material requirements, resolve comments on architectural, mechanical, and electrical components and systems, and resolve comments on the regulatory use of the provisions. In order to assure the future implementation of the refined provisions, NBS will work closely with the Building Seismic Safety Council on each phase of the refinement of the provisions as well as the development 
of a plan for assessing the economic impact of the provisions.

The Interagency Committee on Seismic Safety in Construction established by the President's Earthquake Hazard Reduction Program, will develop improved uniform standards for Federal construction by 1980. The American National Standards Institute Committee has a similar timetable for developing a revised version of ANSI Standard A58 dealing with design loads for buildings. These two groups will be involved with this project and the results will impact future editions of their standards.

\section{Characterization of Soil and Foundation Response to Earthquakes}

Felix Y. Yokel

(301) 921-2648

Structures and Materials Division

Sponsor: National Bureau of Standards

\section{Romania Earthquake Rehabilitation}

Randolph Williams

(301) 921-2196

Structures and Materials Division

Sponsor: U.S. Geological Survey
Relative density is currently used as the single most important parameter in preparing laboratory specimens of sand to model in-situ liquefaction potential. Research now indicates that many other characteristics of the soil are important, such as the manner of deposition, history of preconsolidation, and history of vibration.

A series of pilot tests performed by NBS indicate that the in-situ shear modulus is a major parameter in predicting liquefaction potential. The shear modulus of sand can in turn be measured in-situ by shear wave propagation. This project will test the stiffness hypothesis, provide the information needed for its application in earthquake engineering, and conduct the laboratory test necessary to characterize the parameters which affect the in-situ dynamic response.

Following the March 4, 1977, earthquake in Romania, a team of NBS and USGS engineers visited Romania to inspect earthquake damage and identify ways in which U.S. technology capabilities could be used to aid in postearthquake recovery. Specific recommendations were made to the Romanian Government concerning structural rehabilitation, earthquake monitoring, and earthquake engineering. The USGS has requested that CBT provide guidance to select, purchase, and evaluate instrumentation needed for earthquake engineering research.

The project will include a survey of earthquake engineering laboratories in the United States. A list of earthquake engineering equipment will be compiled and submitted to representatives of the Government of Romania for their approval. NBS will assist USGS with contract documents for the selection, purchase, and acceptance of the instrumentation for earthquake engineering research. 



\section{Strangrures and Foundantons Perrornance}

\section{Structures and Foundations Performance}

\section{Strurgtrures}

and Foundantons Pemprinamee

Strugrumes and Foundantons Perromance

Strunguntes and Foundantons Perfornance

Sirnugures

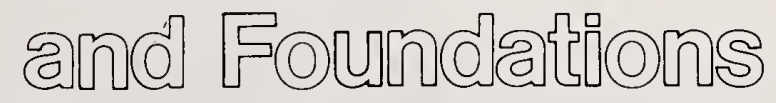
Persormance 


\section{Loading Criteria for Structural Design}

Bruce R. Ellingwood

(301) 921.2170

Structures and Materials Division

Sponsor: National Bureau of Standards
Current structural design standards rely on different philosophies and criteria for design, depending on the material or construction technology used. This tends to complicate design when different technologies are employed in the same structure and differences in philosophy cause a lack of consistency in the reliability levels of different buildings. In recognition of these problems, the trend in Europe and Canada has been toward the development of a common basis for design that would be applicable to all buildings regardless of their material or construction technology. To ensure adequate performance, the unifying concept of limit states has been used, along with a probabilistic treatment of the uncertainties invariably found in engineering design. This project is concerned with the development of design criteria, specifically applicable to building standards in the United States, that will ensure adequate reliability against structural failure and unserviceability. This will lead to reduced building costs by simplifying the design process and stimulating market competition between construction technologies.

ANSI mandates that its standards be reaffirmed or revised periodically to assure that they reflect the latest in engineering knowledge. The state of knowledge regarding loads on buildings has evolved and improved considerably since the current standard was issued in 1973, making its revision necessary. This work will satisfy the clear need on the part of code authorities and design professionals for a design load reference standard which incorporates the latest information on building technology and loads research.

A recent article in Plastics Engineering indicated that, if the construction industry continues to use plastics at the present rate, polymers could emerge as the major class of building components of the 21 st century. While this statement reflects the growing optimism for the future role of polymers in construction, there are technical barriers which slow the rate of growth. In particular, the potential thermal and nonthermal degradation of polymers presents a technical barrier. The purpose of this research is to address the degradation/durability barrier by modeling the thermal and nonthermal degradation of polymeric building components using a reliability physics approach. A major part of this work will focus upon extending research which has demonstrated that solar transmittance decreases over time when selected polymers are subjected to thermal and nonthermal (ultraviolet radiation) stresses. 


\section{Construction Load Evaluation}

Hai S. Lew

(301) $921-2647$

Structures and Materials Division

Sponsor: National Bureau of Standards

\section{Concrete Construction Technology}

Hai S. Lew

(301) 921-2647

Structures and Materials Division

Sponsor: National Bureau of Standards

\section{Mechanical Properties of Maturing Concrete}

Hai S. Lew

(301) 921-2647

Structures and Materials Division

Sponsor: National Bureau of Standards

Snow Loads on Nuclear Power Plant Structures

Bruce R. Ellingwood

(301) $921-2170$

Structures and Materials Division

Sponsor: Nuclear Regulatory Commission
Design load requirements in existing standards for falsework are not adequate and are often identified as a major contributing factor in construction failures. This is due primarily to a lack of documented construction load data. To remedy this problem, a methodology for a field survey of construction loads will be developed. Using specially instrumented shores, live loads on the formwork system will be monitored at actual construction sites, and a set of guidelines will be prepared for submittal to ANSI and other code-generating groups.

Concrete construction is responsible for 25 percent of all construction-related deaths and injuries. Many construction accidents are related to erection and removal of formwork, which is based largely on rule-ofthumb procedures rather than on sound engineering principles. The lack of rational and effective construction methodology has a direct and significant bearing on safety and economy of concrete construction. Improved construction methodology will provide cost savings and considerably reduce construction accidents. Guided by the field survey data on erection imperfections of singlepost shores, a parametric study of variables that affect the strength of shores will be carried out using a computer-based model. The results of the study will be used in the development of a computer model for analysis of construction load distribution between the structure and the formwork.

Removal of concrete forms and supports and the use of concrete structures before the concrete has gained sufficient strength has resulted in collapses of structures under construction. Such construction disasters can be prevented if the strength and stiffness characteristics of concrete at early ages can be determined accurately. Under this project, cylinder specimens cast and cured at various temperatures will be tested. Compressive and tensile strengths and elastic moduli determined from these cylinders will be used to establish strength and stiffness characteristics. The results of this work will be used in the development of guidelines for safe formwork removal.

Current design standards specify snow loads on roofs by multiplying the ground snow load by a snow load coefficient Cs. In ANSI Standard A58.1.1972, Cs depends on roof exposure and geometry. Except in valleys of sloped roofs and locations of elevation change, the load is assumed to be uniformly distributed. However, snow seldom accumulates evenly because of drifting and sliding and the loads may not actually be 


\section{Criteria for Design of Cladding Subjected to Wind Loads}

\author{
Emil Simiu \\ (301) 921-2346
}

Structures and Materials Division

Sponsor: National Bureau of Standards uniform, even on flat roofs. Thermal effects are not included in Cs, despite the evidence that the roof load may be significantly higher for unheated buildings or where the roof is heavily insulated. Finally, the coefficients in A58.1-1972 are based on Canadian studies of ordinary structures: the extent to which these data can be used to represent the different roof geometries in nuclear power plant structures is not clear.

Under this project, technical assistance to NRC to identify roof snow loads and develop loading criteria will proceed in two phases: 1) snow loads on power plant structures will be measured and correlated to ground snow loads for several facilities in the NE quadrant of the United States, and 2) data gathered in phase 1 will be integrated with existing data from similar studies for the purpose of recommending tentative snow load coefficients for design. A report will be prepared for the NRC giving the survey results and recommending snow load coefficients.

Current design criteria for cladding subjected to wind loads are generally recognized to be seriously deficient. The lack of consistency in present criteria results in major economic losses and in safety hazards due to damage to cladding under strong winds. In contrast, uneconomical design of cladding occurs in a large number of design situations. Modern analytical and experimental tools have not yet been applied and/or synthesized in investigating the reliability of cladding subjected to wind loads. Tools from the fields of wind engineering (aerodynamics of bluff bodies in turbulent boundary layer flows), norlinear mechanics of plates, structural reliability and materials testing will be used in this project with a view to developing rational criteria for cladding design. Data from fullscale and wind tunnel investigations of wind loads on cladding will be reviewed and studies will be conducted to determine additional research needs.

The testing of structural models in a wind tunnel is a very effective method, and often the only available method for establishing pressure, lift, and drag coefficients for the design based entirely on the minimum load requirements specified in codes and standards. In recognition of this, the next edition of American National Standards Institute A58.1 (Minimum Design Loads) will allow wind tunnel test data to be substituted for the usual wind load provisions. Therefore, it is essential to establish a set of requirements that will ensure the validity of wind tunnel test results. Existing information on wind tunnel simulation of atmospheric surface flows will be reviewed. The sensitivity of load and response 


\section{Measurement of Forces on Trench Bracing}

Felix Y. Yokel

(301) 921.2648

Structures and Materials Division

Sponsor: National Institutes of Occupational Safety and Health and the Occupational Safety and Health

Administration

\section{Construction Practice in Excavation}

Felix Y. Yokel

(301) 921-2648

Structures and Materials Division

Sponsor: Occupational Safety and Health Administration

\section{Standards for Foundations and Excavations}

Felix Y. Yokel

(301) 921-2648

Structures and Materials Division

Sponsor: National Bureau of Standards and the Department of Housing and Urban Development measurements to the various dimensionless scaling parameters in wind tunnel modeling will also be investigated. The development of minimum requirements for wind tunnel testing of structures covered by the A58.1 Standard will lead to better load definition and, therefore, improved reliability and economy.

Many deaths and injuries result from the cave-in of trenches and excavations (over 200 fatal injuries and many more nonfatal accidents annually). Lack of knowledge of transient forces on trench bracings hamper the engineering profession and hinder the development of effective standards. Data on forces on shallow trench bracing are urgently needed so that analytical methods to calculate forces can be developed. Hydraulic shores will be installed as struts in trenches and forces will be measured via hydraulic pressures. The results will be studied and published in a report on the test methods and results. Conclusions of this work will be used to update the OSHA standard for excavation safety.

More than 200 lives are lost annually in trenching accidents. Excavation practice has been evaluated by NBS and reports prepared on soil classification, trenching timber, and field practices in excavation. A recommended practice for sloping and shoring of trenches and excavation has been prepared and will be published. A number of national workshops will be held under the joint sponsorship of AGC, AFL-CIO, and ASFE, where the NBS recommendations will be discussed. The recommendations will form the basis for new safety standards.

Draft standards in five areas have been prepared in cooperation with ASCE: Piles, piers, excavation, exploration, and shallow foundations. The standards are now being balloted by the ASCE Committee on Foundation and Excavation Standards to become ASCE standards. 


\section{In-Situ Geotechnical Measurements}

William D. Kovacs

(301) 921-2885

Structures and Materials Division

Sponsor: National Bureau of Standards

\section{Construction of the NBS Geotechnical Test Lab}

Riley M. Chung

(301) $921-2127$

Structures and Materials Division

Sponsor: National Bureau of Standards

\section{Mobile Home Anchoring Against Flood and Windloads}

Felix Y. Yokel

(301) 921-2648

Structures and Materials Division

Sponsor: Department of Housing and Urban Development
The first phase of this project deals with the Standard Penetration Test (SPT). A portable field instrument has been built to measure fall height, hammer velocity, and force in a drill stem and present these quantities in the form of energy immediately following a test. To ensure reliability of measurement, the instrument uses two systems: an optical system, measuring hammer velocity and energy above the striker plate; and a mechanical system measuring the stress wave traveling through the rod to measure the energy in the rod below the striker plate. Field tests and calibration of a first generation system have been completed. Another study has been done to evaluate the delivered energy, both above and below the striker plate, to show the variation of energy, some of which may be due to hammer configuration, and to measure the energy actually delivered to the sampler.

This new research laboratory will provide the capability for performing tests to determine static and dynamic stress-strain properties, shear strength, and liquefaction potential of soils. The design was based on recommendations received from a panel of NBS and U.S. geotechnical experts hosted by NBS in December 1979. The initial emphasis is on a soil dynamics capability which will be used to address the liquefaction problem.

The objective of this research is to study the loads, improve the state-of-the-art in mobile home anchoring, and develop criteria. As part of this study, CBT measured windloads and made an analytical study of wind and floodloads. A state-of-the-art study on anchoring technology was also completed and published. A test program on soil anchors is now in progress and a report on the initial results of these tests was presented in the Third Mobile Home/Manufactured Housing Conference. The results of this research will lead to the development of design criteria and standards for mobile home foundations.

Next to fire, wind is the leading cause of deaths and injuries to mobile home occupants and damage to mobile home property. Approximately 5,000 units are heavily damaged or destroyed by wind storms each year. This project involves the collection of existing test data and information on theories and design procedures related to soil anchors. Available data from geotechnical field and laboratory investigations, including direct pull-out tests, standard penetration, cone penetration, and "Soil Test Probe" studies, were assessed. The pull-out resistance of various commercially available ground anchors are being determined experimentally for several loading and soil 


\section{Review of Design Criteria for Energy Transport Systems}

\author{
Richard Marshall
}

(301) 921-3471

Structural and Materials Division

Sponsor: Office of Pipeline Safety

Regulation conditions. The field test data will be correlated with the basic properties of the soils-as determined by standard field and laboratory techniques-to provide a basis for establishing analytical models for predicting pull-out resistance and for performance criteria and a performance test method for foundation and anchor systems. The recommendations and criteria developed in this project will form the basis for provisions to be incorporated in the Federal Mobile Home Construction and Safety Standards.

The Trans-Alaska Crude Oil Pipeline System is the first long pipeline transporting hot crude oil through areas consisting of continuous permafrost. The design of the elevated support system and particularly the vertical support members (VSM) has been under review and discussion for some time because this type of system has not previously been used extensively in permafrost regions. In addition, portions of the pipeline are located in regions of high seismicity. Because of the unusual design and the implications of a loss of integrity, CBT will review the system, with particular attention to earthquake loading, metallurgical properties, lowtemperature effects, and in situ load testing, among other studies.

The annual costs of organic coatings in the United States exceed $\$ 8$ billion. Maintenance costs alone would be significantly reduced if better systems, including surface preparation, were available. In developing test methods and specifications, this project contributes directly to the improvement of the coatings technology used by the military and also contributes to improvement of the Nation's coatings technology through publications, specifications, and participation in ASTM activities. The performance and other characteristics of new organic coating systems will be investigated and test methods developed or modified to assay the performance of these materials. Research will be performed to develop improved field tests for coatings evaluation, study the degradation mechanisms of coatings on galvanized steel, and identify methods for overcoming the problems associated with efflorescence. Also, advisory and consultative services based upon laboratory and field tests will be performed. 


\section{Short-Term Evaluation of Steel Coatings}

Paul G. Campbell

(301) 921.3114

Structures and Materials Division

Sponsor: Federal Highway

Administration

\section{Stone Consolidating Materials}

James R. Clifton

(301) 921-2630

Structures and Materials Division

Sponsor: National Park Service
The Federal Highway Administration wants to reduce the costs of painting steel structures by increasing the painting cycles through the use of improved coating systems. Effective short-term evaluation procedures for evaluating the durability and protective qualities of these coating systems are essential for the success of this goal. Under this project, CBT will evaluate the validity and usefulness of short-term testing used for coatings on steel. Short-term evaluation procedures will be developed for coatings that will provide maximum reproducibility and correlation with service conditions. A users' guide for evaluating and selecting coatings will also be written.

Building stone, once removed from the quarry, is subjected to natural weathering processes. However, the rate of degradation of building stone in urban areas has greatly increased during the past century because of the effects of industrial air pollutants such as $\mathrm{SO}_{2}$ and $\mathrm{CO}_{2}$ gases and acidic rainfall. Certain stones, such as many sandstones, used in historic buildings are especially susceptible to weathering.

Consolidating materials are being extensively used to strengthen the deteriorated stone of historic buildings, with varying degrees of success. In most cases, the evaluation of consolidating materials has been performed by using them on actual buildings, but the results have not usually been well documented. To date, there is no technical basis for selecting stone consolidating materials. This project is aimed at developing these performance criteria. The results will help the National Park Service select stone for future construction and to learn how to better protect existing buildings.

Effective, durable joint sealants are required in the new Dirksen Building for weatherproofing the numerous joints between the various substrates of the structure. Under this project, two samples of joint sealants will be tested in accordance with Federal specifications, with adjustments to these specifications made by the Architect of the Capitol. Substrates, including dark anodized and stainless steel with primers, will be used in conjunction with the sealants. 


\section{Nondestructive Evaluation of Building Materials}

James R. Clifton

(301) 921-2630

Structures and Materials Division

Sponsor: National Bureau of Standards

\section{Elastomeric Roofing Membranes}

Robert G. Mathey

(301) 921-2629

Structures and Materials Division

Sponsor: Department of Defense

Roofing and Coatings Research for the Army

Robert G. Mathey

(301) 921-2629

Structures and Materials Division

Sponsor: U.S. Army
The maturity concept for the curing time of concrete offers one promising method for improving formwork decision-making. The maturity concept relates compressive strength to the combined effect of temperature and curing time. Empirical relations between strength and maturity have been developed with acceptable correlations. However, the validity of these relationships needs to be theoretically tested before they will gain wide acceptance in the construction industry. Based on the conceptual and mathematical relationships developed for the hydration of tricalcium silicate, by Pommersheim and Clifton, relationships will be derived that express the effects of water-to-cement ratios, time, and curing temperature on strength development. The theoretically derived relationships will be tested using available data, and compared to empirically derived equations.

A recently completed study, NBS TN972, Elastomeric Roofing: A Survey, revealed that data are not available on the properties of elastomeric membranes with regard to exposure conditions and aging. It is believed that some elastomeric roofing membranes will exhibit a change in properties when subjected to various exposure conditions and with age. As an example, the level of performance of the weather resistance of elastomeric membranes has not been established. Some factors included in weather resistance are accelerated aging, natural aging, brittleness, dimensional stability, heat aging, ozone resistance, pollutants, volatile loss, loss of plasticizer, and the effects of moisture and temperature. Some membranes may become brittle under cold conditions and have less resistance to tension, impact, and punching shear forces. Aging may appreciably reduce some properties of membranes, particularly when combined with cold environmental conditions. Sustained stress may also reduce the membrane's ability to perform satisfactorily over its intended service life. Because of economic conditions and materials availability the use of elastomeric roofing systems has increased considerably over the last few years. This project will develop information that can be used as a basis for standards and specifications to predict the performance of these systems.

U.S. Army buildings vary widely in construction type and are located in many geographic and climatic areas. Since roofing and coatings have been the source of many of the Army's maintenance problems, this project offers an opportunity to apply laboratory research studies and practical field experience to the solution of special problems. Recommendations will be made for the selection of materials and application methods. 


\section{Blistering of Built-Up Roofing over Polyurethane Insulation}

Walter J. Rossiter

(301) 921-3109

Structures and Materials Division

Sponsor: Tri-Services Committee

\section{Tri-Services Technical and Scientific Support}

\author{
Robert G. Mathey \\ (301) 921.2629 \\ Structures and Materials Division
}

Sponsor: Tri-Services Committee

\section{Improvement of Honeycomb Sandwich Panels}

Jonathan Martin

(301) 921-3208

Structures and Materials Division

Sponsor: U.S. Army
Polyurethane foam insulation has the highest resistanceper-unit thickness of insulation boards used in the construction of built-up roofing systems. It has been reported that there is a higher incidence of blistering of built-up roofing constructed over polyurethane foam insulation than other insulations. Preliminary tests at CBT have indicated that small voids form in the asphalt layer between the membrane and insulation. These voids are attributed to the bubbling and frothing (degassing) of the hot asphalt when applied to the polyurethane foam. The bubbling and frothing may be caused by the degradation of the insulation resulting in degassing, the release of the blowing agent, or the volatization of moisture in the insulation. Under this project, laboratory studies will be conducted to investigate the effect of moisture content in the insulation on the degassing; the effect of hot asphalt on the cell structure of the insulation; and, the effect of temperature on the degassing and decomposition of the insulation cells. Analytical techniques such as thermal gravimetric analysis, gas chromatography/mass spectroscopy, and photomicroscopy will be used.

This project will provide technical and scientific support and consultative services on building materials and systems as required by the Tri-Services. The work will include carrying out laboratory tests and evaluations in the solution of building problems as well as field investigations. Recommendations will be made on the selection of materials and systems and their application and performance. In the past, problem areas have covered plumbing, masonry, roofing, corrosion, mechanical systems, insulation, materials, and underground piping.

All branches of the military use lightweight, airtransportable, rigid structures that serve as combination shipping containers and shelters for many types of tactical and life-supporting services. The use of these shelters has increased rapidly in recent years and lifecycle costs have become a major consideration. The shelters are fabricated from either paper honeycomb core or foam plastic sandwich pan $\epsilon$ !s. While honeycomb panels have several potential advantages, field experience has shown many problems. Poor performance has been attributed to one or more of: improper panel fabrication procedures (adhesive bonding), inadequate performance of the honeycomb core, poor choice of materials, and inadequate design. Under this project, four draft standards will be prepared: for paper honeycomb cores, surface treatment of aluminum for adhesive bonding, selection of adhesives, and the adhesive bonding process. 
Budiding Sarefty

Buil|ding Safefty

Building Safety

Buanding Safferty

Bualding Saf?efy

Budling Saferty

Bunding Saffery

Bundong Sarferty

Bundong Saffefy

Building Sarfery

Building Saffefy

Bund|ling Safenty.

Building Safferty

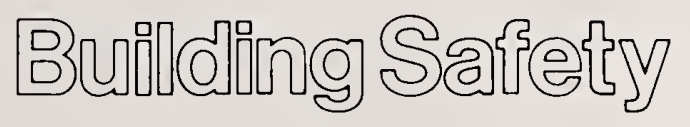




\section{Criteria for Signs in Workplaces}

Robert A. Glass

(301) 921-2246

Environmental Design Research Division

Sponsor: Occupational Safety and Health Administration

\section{Chromaticity Specifications for Color Weather Radar Displays}

Robert A. Glass

(301) 921-2246

Environmental Design Research Division

Sponsor: Federal Aviation Administration

\section{Symbols Criteria and Standardization}

Neil Lerner

(301) 921-2337

Structures and Materials Division

Sponsor: National Bureau of Standards

\section{Modeling Circulation System Safety}

Fred I. Stahl

(301) 921.2627

Environmental Design Research Division

Sponsor: National Bureau of Standards
OSHA has asked CBT to conduct experimental research to improve criteria for new standards for signs in the workplace. Federal agencies now use over 12 different color/legend standards, while private industry is confronted with 20 existing and 5 proposed standards. The adoption of a single, unified system would allow more rapid and more certain recognizability of the meanings of visual displays. This project will address these problems to bring OSHA's current standards on signs into agreement with the latest research findings and with national and international agreements, moving toward a universal set of conventions for visual displays.

The FAA is concerned about "nonstandard" color applications being used in advanced technology displays. Many different manufacturers are supplying a variety of color codes in their display. There is little consistency in the use of color in these displays, especially between those used in aircraft and those used in ground controller operations. Confusion or misinterpretation of communications could occur between the controller and the pilot in interpreting the color display. This project will contribute to a standard color-coding system for allweather radars.

In this project, the research literature on detection, recognition, and perception will be reviewed. Based upon this review and previous research on symbols, a study will assess the effects, of variations in visibility upon the detectability and identification of fire-safety symbols. These results can be compared with research conducted on fire-safety symbols under normal viewing conditions during FY79. Other methods for determining the effectiveness of symbols will also be explored.

Researchers will share results and exchange views with the NFPA Committee on Fire-Safety Symbols and with ISO TC 21 and 80 . In addition, CBT will continue to chair the ANSI Z535 Subcommittee on Symbols.

The design of occupant circulation systems for buildings is often complex and multifaceted, involving both environmental and human behavioral factors. Circulation problems may occur not only during a building's normal use, but whenever such emergencies as fires arise as well. It is often difficult to predict building performance with respect to circulation safety, since the needed tools do not now exist. The BFIRES simulation program, developed earlier under this project, is a new tool intended to aid in the prediction of emergency egress response during fires. This is an example of the type of occupant circulation model which could usefully be 
applied to building design and regulation. The purpose of this project is to continue the process of validating the BFIRES program and modeling approach. This general approach to studying occupant circulation is based on an information processing model of human behavior and on the premise that humans acquire and store various response subprograms (each of which yields a different form of behavior), which are called by a higher level "executive" controller. Thus, not only is the program a potentially valuable design and regulatory tool, it also permits the direct evaluation of an important theory of human behavior.

\section{Security Barriers}

James R. Clifton

(301) 921.2630

Structures and Materials Division

Sponsor: Defense Nuclear Agency
Previous work at CBT has demonstrated that manpassage openings could be produced in security barriers in surprisingly short times using readily available portable equipment. In many instances, these penetrations were produced in working times which have been short enough to require a reappraisal of the use of these barriers for specific physical security applications. These applications include storage of nuclear and conventional weapons, radioactive material, secret documents, and precious metals. Furthermore, the deterrent capabilities of many barriers which are currently accepted for security applications may provide little resistance to penetration by newly developed attack equipment such as the rotohammer, ring saw, Jet-Ax, and burning bar. CBT will identify and determine the effectiveness of materials and methods which can be used to upgrade the penetration resistance of existing security barriers. In addition, materials which can be used in constructing new security barriers having high resistance to penetration will be evaluated. 



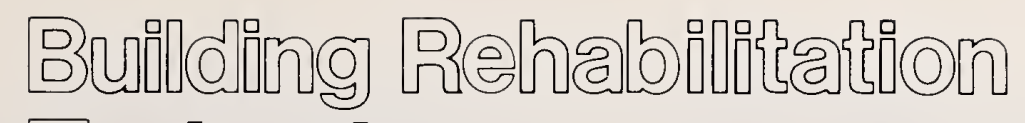
Technology

\section{Building Rehabilitation Technology}

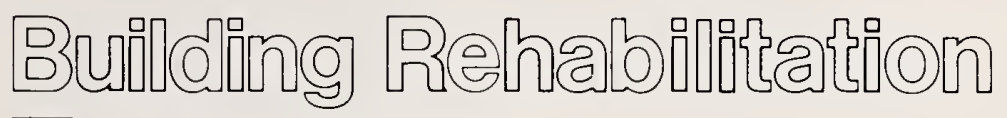
Techorogy

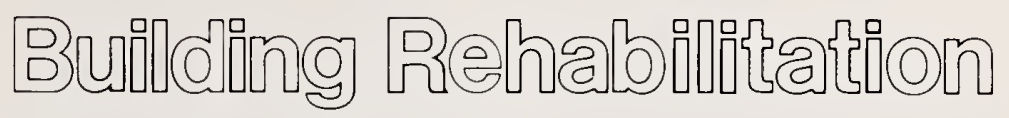
Technology

Bunding Rehabilntanton Technology

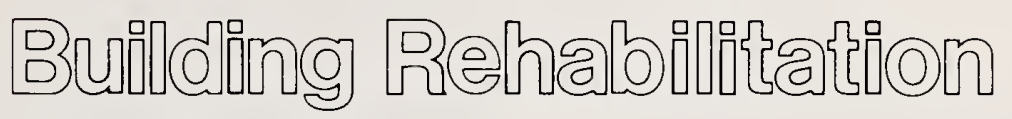
Technology

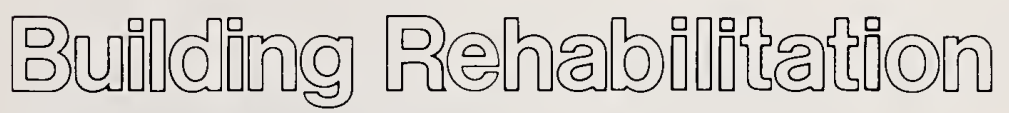
TeGhnology

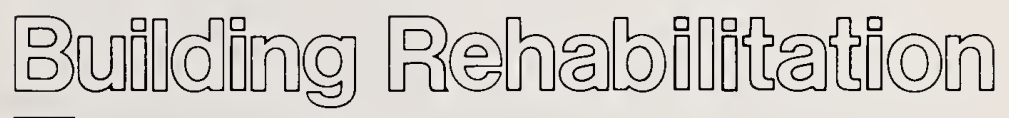
Technology

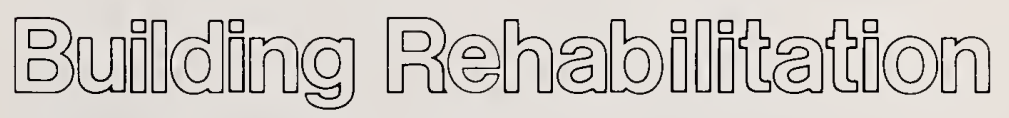
Technology 


\section{Construction Productivity for New and Rehabilitated Buildings}

\author{
Robert Chapman \\ (301) 921-3385 \\ Building Economics and Regulatory \\ Technology Division
}

Sponsor: National Bureau of Standards

\section{Methods for Evaluating the Strength and Stability of Existing Buildings}

Frank H. Lerchen

(301) 921.2776

Building Economics and Regulatory

Technology Division

Sponsor: National Bureau of Standards

\section{Regulatory Provisions for Existing Buildings}

Patrick W. Cooke

(301) 921.2776

Building Economics and Regulatory

Technology Division

Sponsor: National Bureau of Standards
Rapidly rising housing prices and the desire to be centrally located have prompted more and more prospective homeowners to turn toward housing rehabilitation to satisfy their housing needs. One of the crucial issues is the cost of rehabilitation compared to the cost of its alternative-new housing. To a large degree, the cost differential between new and rehabilitation construction is a reflection of differences in productivity between the two construction activities. However, an analysis of productivity and its determinants relates to. more than the cost question. More specifically, it relates to a better understanding of the demands for key factors (labor, materials, and equipment) in the renovation process. A better knowledge of productivity and the associated "factor demand curves" for the rehabilitation process will lead to better cost-estimation procedures as well as provide valuable input to programs designed to mitigate some of the inner city's social problems.

This project addresses the need for technical evaluation procedures to support rehabilitation decisions. A draft recommended practice on strength and stability was developed in FY79 which included methods for assessment of existing construction, including test methods, methods of analysis, and data on archaic construction. It is necessary to broaden the regulatory acceptance of this document by processing it as a consensus Recommended Practice Standard. That achievement will be the goal of this project.

This project involves techinical support in the development of regulatory provisions for existing buildings. CBT conducted a major national conference on building rehabilitation to provide a forum for those involved to share technical expertise and identify research needs. Technical issues included code development, energy conservation, seismic design, legal, and economic concerns. The Center also provided support to regulatory organizations through consultation on NBS technical output to further application of research results and identify needs. The fifth Annual NBS/NCSBCS Joint Conference on Research and Innovation in the Building Regulatory Process was held in support of this activity. 


\section{Performance Levels for Existing Buildings}

James H. Pielert

(301) 921-3146

Building Economics and Regulatory

Technology Division

Sponsor: National Bureau of Standards

\section{Ventilation Criteria for Existing \\ Buildings}

Tamami Kusuda

(301) 921-3501

Building Thermal and Service Systems

Division

Sponsor: National Bureau of Standards

\section{Guidelines for Venting Single-Stack Drainage Systems}

Paul Kopetka

(301) 921-2136

Building Thermal and Service Systems

Division

Sponsor: National Bureau of Standards
As increased emphasis is placed on the reuse of existing buildings, it becomes more important that new approaches be used to assist in making decisions in regard to rehabilitation. The application of performance criteria provides flexibility in the use and acceptance of design alternatives in lieu of prescriptive provisions. It is important that the technical base and rationale of code provisions be well established so that there is logic and flexibility for technical decisionmaking. Under this project, a methodology will be developed for assessing the technical bases of building code provisions and developing performance levels for existing buildings.

Increasing use of energy conservation measures has aroused concern that many indoor pollutants can reach dangerously high levels. Levels of aerosols from cigarette smoke and cooking, $\mathrm{NO}_{2}$ and $\mathrm{CO}$ from combustion, radioactivity due to radon daughters originating in radon emitted by building materials, soil, water and natural gas, insecticides, and organic vapors from cleaning materials can all rise in tightened buildings. Increased humidity can cause discomfort and increased growth of molds, bacteria, and viruses, which could lead to increased infectious disease and allergies. Under this project, the technical basis of energy conservation and ventilation requirements in codes and standards for existing buildings will be evaluated and revisions recommended where necessary to reflect existing epidemiological and other medical data. They will take into account natural air leakage, energy consumption for heating and cooling, and health requirements in a unified, consistent manner.

Current plumbing criteria require venting to prevent trap seal failure. Systems without separate venting have performed satisfactorily as demonstrated in Philadelphia, throughout Europe, and in special single-stack systems. However, acceptability in the United States is relatively low because of traditionally conservative plumbing codes and difficulties in gaining acceptance of innovations. Permissible safe installations with limited venting are required for economic rehabilitation. Additional drainage stack piping bypass "loops" performing the functions of the splitter in a single stack design have the potential of providing safety for prevention of trap seal failures. Fabrication from continuous piping, particularly plastics, can be a very economical retrofit measure. Where minimal venting (under current codes) in existing buildings can be tied into relief network circulation loops, the trap seal retention appears promising. The feasibility of this approach applied to existing buildings will be evaluated under this project. 


\section{Restoration Standards for Porcelain Finishes}

Paul G. Campbell

(301) 921-3114

Structures and Materials Division

Sponsor: Department of Housing and Urban Development

\section{Metric Conversion Scheduling in the U.S. Building Community}

\author{
Sandra A. Berry \\ (301) 921-2689 \\ Building Economic and Regulatory \\ Technology Division
}

Sponsor: National Bureau of Standards

\section{Design and Construction Technology Application Program}

\author{
Porter Driscoll \\ (301) 921.3106 \\ Center for Building Technology \\ Headquarters
}

Sponsor: National Bureau of Standards
The maintenance of porcelain enamelled fixtures has been a major concern to HUD. Restoration of fixtures by application of organic coatings to the damaged porcelain surfaces may cost one quarter as much as replacement. The evaluation of the performance of commercially available finishes, recommendations for performance criteria for their selection, and standards for applications are essential for the successful use of these restoration finishes. To fill this gap, CBT will evaluate the performance of restoration finishes by laboratory test methods. The end result will be a set of performance criteria for these materials.

Over the past 5 years, the ANMC Construction Industries Coordinating Committee (CICC) has developed a comprehensive metric conversion plan and a schedule of the processes and times involved to convert the entire construction sector to using SI units. For metrication of the construction industry to proceed, there is need to obtain industrywide agreement on a plan for metric conversion which represents a commitment on the part of the U.S. construction community.

CBT will participate with the National Institute of Building Sciences (NIBS), ANMC, the U.S. Metric Board, and industry in planning and conducting a national conference which will consider the opportunities and problems related to metric conversion of the construction community, and determine whether or not the construction industry should convert to the metric system of measurement. CBT will develop a report giving background on the needs for and impacts of metric conversions. The schedule for metric conversion will be described and significant milestones in the process identified.

The objective of this program is to improve building practices by identifying researchable problems in cooperation with the design and construction communities directly and through their professional and trade organizations. Design and construction community input is provided to research project leaders for the precise definition of the problems to be answered and as a continuing resource during the research. Research findings and other technical information are converted as necessary into forms usable by the design and construction communities. Projects include studies of the architect's access to information and ways of making information useful to architects, noise control and corrosion control for designers, color rendition under high-efficiency lighting, innovative rehabilitation regulations, window design for energy conservation, and simplified economics for energy analysis. These and 
other subjects are reported in CBT publications and audiovisuals designed for architects, engineers, planners, and builders. 



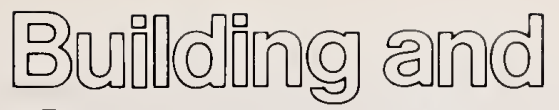 Coñnumintitasenstics}

\section{Building and Community Acoustics}

Buidoling and Community Aseustices

Buำ|ling and

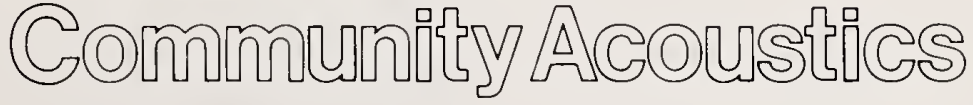

Budiding and Communitivy Algousthes

Buniling and

Community AGoustices

Building and]

Communintiy/ AlGoustices

Bufi[ding and Community Aseoustics

Bufl[ing and Communitivy AGousthles 


\section{Building Acoustics Technology}

Simone L. Yaniv

(301) 921-3646

Environmental Design Research Division

Sponsor: National Bureau of Standards

Highway Noise Criteria

Simone L. Yaniv

(301) 921.2263

Environmental Design Research Division

Sponsor: Federal Highway

Administration
This project will develop design criteria for noise isolation of building spaces: acoustic parameters affecting user responses will be identified through field sampling of selected outdoor environments and building types. Using physical data obtained in the field and simulation of isolation characteristics of actual and modified building structures, psychoacoustic studies will be conducted under laboratory control to provide technical bases for standards on the noise isolation of building shells and party walls. To develop standardized measurement methods for outdoor-to-indoor noise isolation, sound fields in and around buildings will be characterized by land use, location and orientation of building relative to noise sources and building stereology (i.e., height, length, shape). With this characterization, it will be possible to standardize the locations for measuring spatial and temporal variation in sound pressure levels. This work also includes building sites.

Noise from highways and urban traffic has been shown to be a serious source of annoyance to the public. Many Government agencies, including the Federal Highway Administration, are trying to solve the problem. The FHWA is responsible for highway projects. FHWA seeks to reevaluate its interim noise standards and procedures, incorporating considerations of human response to time-varying rather than steady-state noise. CBT has been contracted to provide FHWA with a data base on the human response to time-varying traffic noise necessary for this reevaluation.

CBT has analyzed the time histories and spectra of traffic noise from different traffic situations and has data on how traffic sounds are received in a building. Laboratory investigations are planned on the human response to the time-varying noises. From analysis of these experiments and in conjunction with the analysis done on the physical data base, it will be possible to evaluate existing rating schemes and, if necessary, develop an improved rating procedure. A questionnaire and measurement plan will be developed to assess occupant reactions to highway noise based on the key parameters.

The most economical means for long-distance transport of electric energy is the overhead, high-voltage electric transmission line. Increases in transmission efficiency are achieved by increases in operating voltages. However, one of the major factors limiting the development of new ultra-high-voltage technologies is the audible (corona) noise produced by these lines under certain conditions. To manage this noise and to avoid costly retrofit measures, the project will obtain psychoacoustic data for 


\section{Impact Noise Measurement}

Peter H. Huang

(301) $921-3383$

Environmental Design Research Division

Sponsor: National Bureau of Standards

\section{Sound Absorption Measurement}

Thomas W. Bartel

(301) 921-3783

Environmental Design Research Division

Sponsor: National Bureau of Standards land-use planning in the vicinity of power lines, and for construction planning for nearby building sites.

Corona noise samples for different weather conditions and from different transmission lines will be recorded with a remote tape recording system. In the laboratory these recordings will be processed along with recordings of other environmental sounds into stimulus tapes. These tapes will then be evaluated by listeners under realistic conditions approximating natural built environments. The effect of the building shell on the listener's response to corona noise will also be determined. On the basis of people's responses, criteria will be developed for characterizing the acoustic environment near transmission lines in terms that are relevant to human response, so that decisions about land use planning, building design, and construction may be based on users' needs.

The major source of impact noise in multi-family buildings, office buildings, and institutional buildings is that produced by the impact of human footfalls, falling objects, and furniture dragging on floor-ceiling assemblies. The present standard test method for assessing floor-ceiling assemblies uses the ISO "tapping machine." But this method yields results that are misleading.

Under this project, the time domain characteristics of footfalls will be determined using the force-measuring platform. That is, the rise time and duration of the impact signature will be determined as a function of shoe size, style, weight, height, rate of footfalls and various walkers. The results of this work will be used for more reliable theoretical predictions of sound through floor. ceiling assemblies.

For many building spaces the intelligibility of speech and music is as important as the control of unwanted noise. Optimal acoustics within an enclosed space are achieved by control of reverberation time, which is related to the amount of sound absorption contained in the enclosure. In addition, the total sound absorption within a room is one of the parameters that controls noise level within the room and determines occupant acceptance and productivity. At present, the sound absorption of acoustical materials is inferred from measurements of reverberation time (sound decay) conducted in a reverberation chamber. This uncertainty in the measurement of sound absorption and the lack of knowledge about most materials results in costly overdesign and excessive reliance on special expensive absorbent materials. This project will result in improved 
procedures for measuring sound absorption in the reverberation chamber and for predicting reverberation times. A tool for measuring the acoustical absorption in the field will be developed as will the data base, required by architects and designers, on the absorption of nonproprietary materials.

\section{Method for Assessing Costs of a Model Noise-Control Code}

\section{Stephen F. Weber}

(301) 921-2308

Building Economics and Regulatory

Technology Division

Sponsor: Environmental Protection

Agency
To encourage adequate noise control in building design and construction, the Environmental Protection Agency (EPA) has prepared a Model Noise Control Code (MNCC) for residential and educational buildings as well as an accompanying implementation manual. In addition to reducing noise intrusion in buildings, the application of provisions of this MNCC could lead to increased construction costs, and possibly to operating-cost reductions to the form of energy savings.

The objective of this effort is a consistent method for assessing the costs of applying provisions of the MNCC to the two building types they address: multi-family residential and educational. The cost categories covered by the method are construction costs and energy consumption costs. The first step in developing the method is to determine which components of the two building types would be most directly affected by the MNCC. Next, a set of typical construction methods will be established for each affected component. For each construction method, existing standard practice will be established to provide a benchmark against which the impacts of MNCC can be measured. Then construction cost estimating guides will be used to determine the unit cost for each component and construction method. 
Bundoling Service Systems Perrfrrnance

\section{Building Service Systems \\ Performance}

Buifoling Servinee Systems Perfornance

Bundoling Service Systems Performance

Buildong Service Systems Perfornance

Bupidoling Servince Systems Perfornamee 


\section{Plumbing Systems Performance}

Lawrence Galowin

(301) 921-3293

Building Thermal and Service Systems

Division

Sponsor: National Bureau of Standards

Performance of Water-Conserving

Devices

Lawrence S. Galowin

(301) $921-3293$

Building Thermal and Service Systems

Division

Sponsor: Department of Housing and Urban Development
The plumbing community has identified the need for revision of storm drainage systems design criteria as a result of new weather load data information. Present storm drainage systems are thought to be oversized, resulting in wasteful use of piping materials. Likewise, code acceptance of reduced size venting (RSV) for hospital plumbing systems with head/pipe network circulation requires validated modeling techniques for design predictions. Currently, gaps in sound theoretical formulations for the fluid dynamics of pressure relief to prevent trap failures are based on empirical factors from inadequate data sources. Similarly, three-phase flow in plumbing systems is characterized by transient, random, unsteady, partially filled pipes with three phase (airwater, solids) dynamic interactions. The capability for developing mathematical solutions is required for such complex phenomena within interconnected pipes.

Research in all three of these areas will continue during FY80.

The research in the residential water conservation program is directed primarily at laboratory-based investigations to develop data, test procedures, predictive modeling for design applications and to provide recommendations for plumbing standards, codes, and rating systems for performance of low-water-usage devices. Human factors and economic studies are included to evaluate incentives and motivations for water savings. The requirements developed also establish a uniform basis of water savings criteria for HUD Minimum Property Standards. Incentives for manufacturers in supplying plumbing products which meet low water usage can be provided under uniform requirements, expressed in performance terms, which will be common across the United States. Research at CBT and at Stevens Institute of Technology (under contract to CBT) includes the total building plumbing water system; i.e., water supply distribution, devices, fixtures and appurtenances, waste drainage branches, soil stacks and connections to sewers/on-site treatment facilities.

A recently completed literature review indicates that reliable quantified data have not been established from field research in the area of occupant response to specific water conservation devices. The laboratory-based hydraulic parameters associated with showerheads have been established. However, it is not known how to relate those parameters to consumer requirements. Showerhead manufacturers and HUD officials have indicated the need for data relating the physical characteristics of showerheads to user response. This project will conduct a pilot study to evaluate user response to specific 


\section{Economically Efficient Water Conservation Standards}

\author{
Stephen F. Weber \\ (301) 921-2308 \\ Building Economics and Regulatory \\ Technology Division
}

Sponsor: Department of Housing and Urban Development

\section{Electrical Distribution Systems Protection}

Robert W. Beausoliel

(301) 921-3454

Building Thermal and Service Systems

Division

Sponsor: National Bureau of Standards showerheads. Showerheads instrumented to measure water pressure and temperature will be distributed to volunteers. The data records will include the instrument readings and a record of the duration of each shower and also provide specific responses and open-ended commentary.

HUD has recognized the need for a technology data base to gain objective water conservation standards in residential buildings. However, the need to conserve water depends on local conditions such as the scarcity of water in the area, the capacity of the local water supply and wastewater treatment systems, the local utility cost structure and availability of capital funds, and the relative growth/decline of the local population. The use of water-efficient fixtures, fittings, and appliances is only one of several ways to conserve water. Metering and pricing policies, leakage control, water pressure control, education programs, and industrial water conservation are other important ways to conserve. The output of this research will be a report to HUD that describes the economic framework for water conservation. The report will be distributed to local water utilities, the Water Resources Council, the Office of Water Resources Research and Technology (Department of Interior), the Environmental Protection Agency, selected water resource researchers, and to plumbing standards and code organizations.

NFPA fire statistics indicate that electrical failures cause the largest number of building fires. Annually, about 100,000 fires are attributed to building electrical systems, and 60,000 additional result from motors and appliances. CBT laboratory results demonstrate that common overcurrent protection devices do not provide adequate protection against fire during short-circuits. This project will approach this problem through a computer program for predicting temperatures of electrical wiring and overcurrent protection devices. Work will also be done on conducting leakage current and dielectric breakdown limits as a function of temperature. Researchers will develop functional performance requirements and criteria for over-current and ground fault protection devices. 



\section{Lighhting Techmology}

Lighthing Teahnology

\section{Lighting Technology}

Lighthring technology

Lighthing TeGhnology

Lighthing Technology

Lighthing TeGhnology

டighrting TeGhology

Lighthing Technology

Lighthing Technology

Lighthing Techno|logy

[ighhting Jechnology

Lighthing Technology

Lighrting TeGhnology 


\section{Lighting Design Evaluation}

Arthur I. Rubin

(301) 921.2117

Environmental Design Research Division

Sponsor: National Bureau of Standards

Task Lighting Criteria

Gary T. Yonemura

(301) 921.2680

Environmental Design Research Division

Sponsor: Department of Energy
The improvement of current lighting practices depends on: a better technical understanding of the effectiveness of lighting systems under actual use conditions; identifying the gaps in available knowledge to determine what lighting research is needed; performing the research to close the gaps; and validating, under field conditions, research recommendations. This project focuses on determining lighting requirements from the standpoints of the end-user, architect, lighting designer, and visual researcher. Laboratory and field measurement requirements to evaluate lighting systems will also be conducted.

Laboratory research at CBT, first using grating patterns, and then employing printed matter (realistic tasks) indicates that when visual performance is measured by apparent equal contrast contours, the function is different from that obtained when the visual task is detection-the procedure used to obtain presently used levels of illumination. An experimental methodology is being developed for recommending "goodness of task visibility" for sustained performance of office type tasks, under conditions simulating real-world conditions. The research findings obtained to date will serve as the basis for a paper describing how the laboratory approach can be applied to lighting design practices.

Under this project, an interim set of criteria for energyconserving building illumination systems will be delivered to an ANSI committee for development and processing as a voluntary consensus standard.

Reproducible standard tasks and portable luminance spotmeters, developed and characterized under an associated CBT project, will be used to measure the effectiveness (quantity of illumination versus energy consumption) of installed lighting systems in operating buildings. A field measurement method will be developed to enable untrained personnel to determine lighting system effectiveness.

Building illumination practice has relied upon simplistic measurements of illumination levels, poorly defined reflectance values, and complex calculation schemes based upon inadequate data. The new requirements for more cost-effective, energy conserving illumination systems are creating a demand for more precise, valid physical measurement techniques to guide systems design, evaluate the effectiveness of prototype and installed lighting systems, and contribute to the physical basis of vision research. The development of precise physical-measurement techniques in illumination under 


\section{Applied Color and Vision}

Gerald L. Howett

(301) 921.2670

Environmental Design Research Division

Sponsor: National Bureau of Standards

\section{Visual Environment}

Gary T. Yonemura

(301) $921-2680$

Environmental Design Research Division

Sponsor: National Bureau of Standards

\section{Visual Techniques in NDE}

Gary T. Yonemura

(301) 921-2263

Environmental Design Research Division

Sponsor: National Bureau of Standards this project will directly support voluntary standards and advances in vision and illumination (artificial and natural) research.

Since lighting energy costs are an important component of office-building life cycle costs, improvements in lighting efficiency are sought. However, adverse user reaction to poor color rendition can reduce the effectiveness of a workforce. More important, it is known from research on both humans and lower animals that long-lasting changes in vision can result from exposure to strong white light or moderately intense colored light. A series of experiments will be carried out in which observers are exposed to various durations of several different types of lights. Immediately thereafter, the observers will be tested for changes in visual sensitivity over a period of time. These studies will be repeated at several luminance levels of preadapting light, all within the range currently regarded as not harmful to humans.

Current lighting design practices are questioned by architects and lighting designers-especially in view of the current needs for energy conservation. The project deals with recommended practices, standards, and energy conservation in building illumination such as recommended levels of illumination, and assessment of lighting system effectiveness. This project is examining the basic concepts involved in assessment and predictions, with emphasis on determining the applicability of findings for human observers under illumination conditions existing in the everyday work environment.

Much is known about visual processes, per se, but the visual conditions, techniques, and information capacity required of the observer, as specifically related to NDE, are not firmly established. Field observations and interviews with NDE experts to identify the visual information parameters associated with typical NDE sites and tasks will be conducted. In this project for NBS's National Measurement Laboratory, microphotometric and microdensitometric measurements will be made of NDE tasks encountered in practice. The quantitative descriptions of defect parameters will serve as the base from which visual standards and methodology to assess and calibrate the "eye" will be derived. 

Buniding EGonomics

Building Egonomics

Building Economics

Buid|ling EGonomics

Buddong EGonomics

Building EGomomics

Buadong EGonomics

Buil|ling EGonomics

Building EGomomics

Buniling EGonomics

Buiding Egomomics

Buniding EGonomics

Building Eeonomics

Building EConomics 


\section{Economic Methods for Building Standards}

Harold E. Marshall

(301) 921-3701

Building Economics and Regulatory

Technology Division

Sponsor: National Bureau of Standards

\section{Economic Impact of Electronics Research}

Carol Chapman Rawie

(301) 921-2278

Building Economics and Regulatory

Technology Division

Sponsor: National Bureau of Standards

\section{Quantitative Optimization Techniques}

\section{Robert Chapman}

(301) 921-3385

Building Economics and Regulatory

Technology Division

Sponsor: National Bureau of Standards
Improved methods and guidelines are needed to help the building community produce buildings that meet performance requirements but that are still affordable. Here, research will be conducted on the savings-toinvestment ratio, the internal rate of return, discounted payback, and other life-cycle or benefit-cost analysis types of economic evaluation. Existing methods will be investigated, and where appropriate, they will be adapted or revised to provide the best methods for buildings and building components. Definitions of economic terms, illustrative case examples using the methods, and computational aids in applying the methods will also be provided. Outputs of this research will be provided to ASTM in a form that will help them implement economic standards. Related research will also be undertaken on how to measure the economic impacts of building code requirements. Hypothetical case studies will be added to earlier work on ground circuit fault interrupters to illustrate the application of economic analysis in several types of code situations.

Because of the scarcity of funds available for research, there is increasing need for Government agencies, including scientific agencies such as NBS, to be aware of the economic impact of their activities. But measuring the value of Government scientific research is difficult, partly because the information that results is usually distributed freely rather than being bought and sold like ordinary goods. Thus, NBS managers need a workable method for measuring the economic impacts of their research projects. The purpose of this study is to develop and apply a method of estimating such economic impact. It will do so through a case study of the economic impacts of research performed at the NBS Center for Electronics and Electrical Engineering.

Under this project, a computer model for predicting renovation costs of institutional buildings will be transmitted to HEW and to the VA for their immediate use in making renovation decisions for health care facilities. Statistical information collected in a survey of health care facilities will be used to construct cost functions for different types of health care facilities. New cost functions will be used to find more cost-effective approaches to comply with existing building codes. 
Economics Participation in Conferences, Workshops, and Seminars

Rosalie T. Ruegg

(301) 921.2330

Building Economics and Regulatory

Technology Division

Sponsor: Department of Energy
Under this project, CBT will develop technical material on solar economics for the Solar Design Workshop and participate in a series of three training workshops on solar energy in Federal buildings. 



\section{Building( \\ connmunifity Indexz}

\section{Building}

Community Index

Buid|ding

comanumaity lindex

Buidding

communadity Index

Bualoling

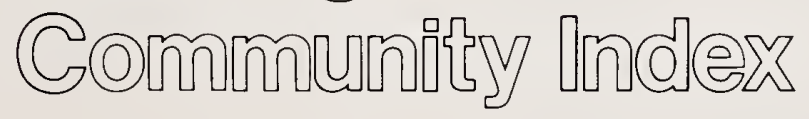

Buflding

Communaity Index

Buofdilng

community Indexs

Bufiding

communarty Inders 


\section{BUILDING COMMUNITY INDEX}

The following listing presents the CBT projects organized by their interest to segments of the building community. The projects are listed under the appropriate building community groups as noted below.

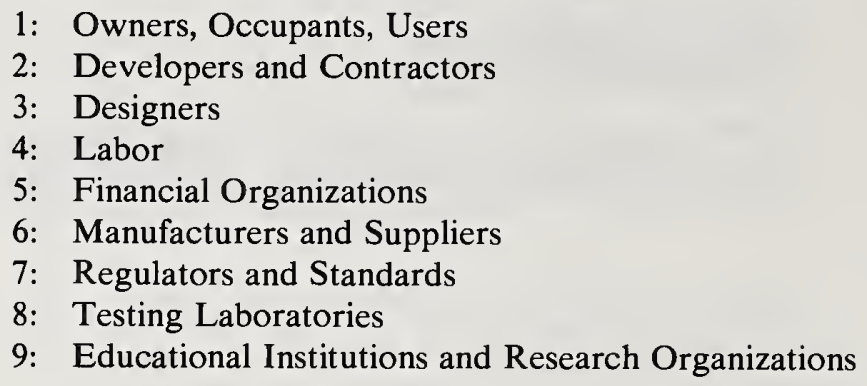

\section{ENERGY CONSERVATION IN BUILDINGS}

Energy Analysis: Norris Cotton Building, p.2

Energy Analysis Procedures, p. 2

Energy Audit Procedures for Commercial Buildings, p. 3

Dynamic Performance of HVAC Systems and Controls, p.3

EMCS Reliability Study, p.3

EMCS Computer Modeling, p.3

Energy Analysis of Control Strategies, p.4

Retrofit Instrumentation Technology/EMCS Sensors, p.4

Thermostat Test Standard, p. 4

Evaluating the Performance of Heat Pumps, p.5

Heat Pump Studies, p. 5

Part-Load Performance of HVAC Equipment, p. 5

Furnace Studies, p. 6

Central Air Conditioner Studies, p. 6

Central Air Conditioner Test Procedures, p. 6

Technical Evaluation Manual for Energy Conservation, p.7

Building Energy Performance Criteria, p.7

Retrofit Training Criteria, p. 8

Revision of Bioclimatic Chart, p. 8

Daylighting Studies, p. 8

Daylighting Prediction Methodology, p.9

NFC Research Associate Program (Daylighting), p. 9

Life-Cycle Cost Methodology, p.10

Cost-Effectiveness of Infrared Heat-Loss Surveys (Ground-Based), p. 10

Infrared Aerial Survey Evaluation, p. 10

Weatherization Demonstration, p. 11

Building Infiltration Evaluation, p. 11

Guidelines for Controlling Attic Condensation, p. 12

Modeling Cooling with Whole-House Fans, p. 12

Underground Heat Distribution Systems, p.12

Energy Conservation Through Waste Use in Cement and Concrete, p.13

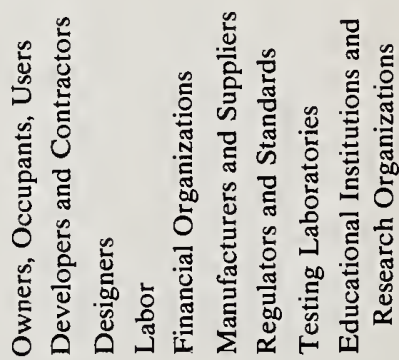

$\begin{array}{lllll}X & X & X & X\end{array}$

$\mathrm{X} \quad \mathrm{X} X \mathrm{X} X$

$X \quad X \quad X X X$

$\begin{array}{llllllllllllllll} & X & X & X & X\end{array}$

$\begin{array}{lllllllllllll}X & X & X & X\end{array}$

$\begin{array}{llll}X & X & X\end{array}$

$X \quad X \quad X$

$\begin{array}{llll}X & X & X\end{array}$

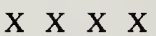

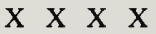

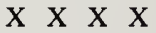

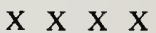

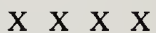

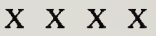

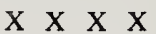

$\begin{array}{lllll}X & X & X & X\end{array}$

$X \quad X \quad X \quad X$

$\mathrm{X} \quad \mathrm{X}$

$\mathrm{X} \quad \mathrm{X} \quad \mathrm{X}$

$\begin{array}{lll}X & x & X\end{array}$

$\begin{array}{llllll}X & X & X & X & X\end{array}$

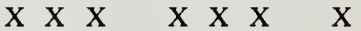

$\begin{array}{lllll}X & X & X & X\end{array}$

$\mathrm{X} X \mathrm{X}$ X $\mathrm{X}$ X

$X \quad X$

\begin{tabular}{lllllllllll}
$X$ & & & $X$ & & & $X$ \\
$X$ & $X$ & $X$ & $X$ & $X$ & $X$ & $X$ \\
\hline & & & $X$ & $X$ & & &
\end{tabular}

$\begin{array}{lllllllllll}X & X & X & X & X & X & X & X & X \\ X & X & X & & & X & X & X & X\end{array}$

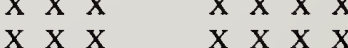

$\mathrm{X} \times \mathrm{X} \quad \mathrm{X} X \mathrm{X} X$

$\begin{array}{lllll}X & X & X & X\end{array}$

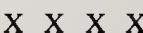

$\begin{array}{llllllll}X & X & X & X & X & X & X & X \\ & X & & X & X & X & X \\ & & X & & X & X & X & X \\ X & X & X & & X & X & X & X\end{array}$


Modeling Mass Effects with Outside Insulation, p. 17

Experimental Evaluation of Thermal Mass, p. 17

MIMA Research Associate Program, p. 18

Guarded Hot-Plate Tester for Thick Insulation, p. 18

Calibrated Hot Box Construction, p. 18

Corrosion Avoidance in Encapsulated Wiring, p. 18

Retrofit Criteria: Insulation and Wiring, p. 19

\section{BUILDING SOLAR SYSTEMS TECHNOLOGY}

Collector Durability and Reliability Test Program, p. 22

Standards for Rubber Hose and Connections, p. 22

Standards for Solar Cover Plates, p. 23

Standards for Nonmetallic Containment Materials, p. 23

Standards for Solar Absorptive Coatings, p. 24

Evaluation of IPC Corrosion Test Methodology, p. 24

Solar Hot Water System Test Program, p. 24

Structural Performance of Solar Collectors, p. 25

Thermal Test Methods for Solar Collectors, p. 25

Passive Solar Data Requirements, p. 25

Economic Evaluation of Passive Solar Designs for Urban Environments, p. 26

Installation of Solar Components on Roofs, p. 26

Solar Evaluation of the Norris Cotton Building, p. 26

Monitoring Methods for Low-Cost Residential Solar Systems, p. 27

Commercial Solar Energy Demonstration, p. 27

Solar Energy Program for Housing Systems, p. 27

Dimensional Considerations in Solar Installation, p. 28

Solar Federal Buildings Program, p. 28

Federal Procurement Specifications for Solar Heating and Cooling, p. 28

Economic Optimization Guide for Solar Systems in Federal Buildings, p. 29

Technical Evaluation Manual for Solar Retrofit of Federal Buildings, p. 29

International Cooperation in Solar Energy, p. 29

Residential Solar Data Center, p. 29

Development of Solar Regulatory Provisions, p. 30

Code Analysis of Thermal Energy Storage, p. 30

Solar Utilization in Cities and Towns, p. 31

Combined Photovoltaic/Thermal Solar Systems, p. 31

\section{EARTHQUAKE HAZARD REDUCTION}

Characterization of Structural Response to Earthquakes, p. 34

Seismic Provisions for Buildings, p. 34

Characterization of Soil and Foundation Response to Earthquakes, p. 35

Romania Earthquake Rehabilitation, p. 35

\section{STRUCTURES AND FOUNDATIONS PERFORMANCE}

Loading Criteria for Structural Design, p. 38

Development of Revisions to American National Standards Institute A58, p. 38

Application of Reliability Analysis Concepts to Building Components, p. 38

Construction Load Evaluation, p. 39

Concrete Construction Technology, p. 39

Mechanical Properties of Maturing Concrete, p. 39

Snow Loads on Nuclear Power Plant Structures, p. 39

Criteria for Design of Cladding Subjected to Wind Loads, p. 40

Criteria for Wind Tunnel Modeling, p. 40

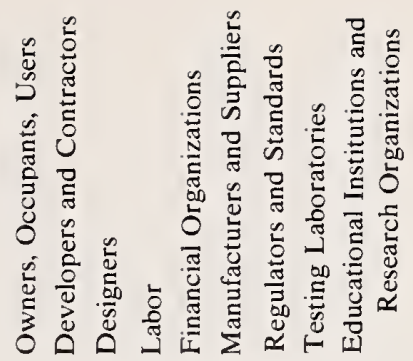

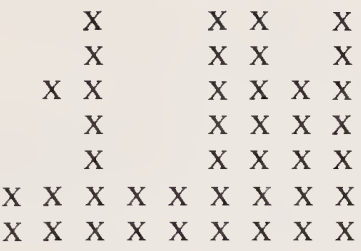

\begin{tabular}{|c|c|c|c|c|c|c|}
\hline & & X & & $X$ & $X$ & $X$ \\
\hline & & $X$ & & $\mathrm{X}$ & $X$ & $X$ \\
\hline & & X & & $X$ & $\mathrm{X}$ & $X$ \\
\hline & & X & & $X$ & $X$ & $\mathrm{X}$ \\
\hline & & $X$ & & $X$ & $X$ & $X$ \\
\hline & & $X$ & & $X$ & $\mathrm{X}$ & $X$ \\
\hline & & $X$ & & $X$ & $X$ & $X$ \\
\hline & & $X$ & & $X$ & $X$ & $X$ \\
\hline & & 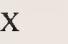 & & $X$ & $\mathrm{X}$ & $X$ \\
\hline & & $X$ & & $X$ & $\mathrm{X}$ & \\
\hline & & $X$ & & $X$ & $\mathrm{X}$ & \\
\hline & & $\mathrm{X}$ & & $X$ & $\mathrm{X}$ & $X$ \\
\hline$X$ & $X$ & $X$ & $X$ & $X$ & $\mathrm{X}$ & $X$ \\
\hline & & $X$ & & $X$ & $X$ & \\
\hline & & $X$ & & $\mathrm{X}$ & $X$ & \\
\hline $\mathrm{X}$ & $X$ & $X$ & & $X$ & $X$ & \\
\hline & & $X X$ & & $X$ & $X$ & \\
\hline & & $X$ & & $X$ & $X$ & \\
\hline & & $X$ & & $X$ & $X$ & \\
\hline & & $X$ & & $X$ & $X$ & \\
\hline & & $X$ & & $X$ & $\mathrm{X}$ & \\
\hline & & $X$ & & $X$ & $X$ & \\
\hline & $X$ & $X$ & & $X$ & $X$ & $X$ \\
\hline & & $X$ & & $X$ & X & \\
\hline & & $X$ & & $X$ & $X$ & \\
\hline$X$ & $X$ & $X$ & & $X$ & $X$ & \\
\hline & & $X$ & & $X$ & $X$ & \\
\hline
\end{tabular}

\begin{tabular}{|c|c|}
\hline$X$ & $X X$ \\
\hline$X$ & $X X$ \\
\hline$X$ & $X X$ \\
\hline$X$ & $X X$ \\
\hline
\end{tabular}


Measurement of Forces on Trench Bracing, p. 41

Construction Practice in Excavation, p. 41

Standards for Foundations and Excavations, p. 41

In.Situ Geotechnical Measurements, p. 42

Construction of the NBS Geotechnical Test Lab, p. 42

Mobile Home Anchoring Against Flood and Windloads, p. 42

Anchoring Mechanics for Mobile Homes, p. 42

Review of Design Criteria for Energy Transport Systems, p. 43

Organic Coatings, p. 43

Short-Term Evaluation of Steel Coatings, p. 44

Stone Consolidating Materials, p. 44

Evaluation of Joint Sealants for the Dirksen Building, p. 44

Nondestructive Evaluation of Building Materials, p. 45

Elastomeric Roofing Membranes, p. 45

Roofing and Coatings Research for the Army, p. 45

Blistering of Built-Up Roofing Over Polyurethane Insulation, p. 46

Tri-Services Technical and Scientific Support, p. 46

Improvement of Honeycomb Sandwich Panels, p. 46

\section{BUILDING SAFETY}

Criteria for Signs in Workplaces, p. 48

Chromaticity Specifications for Color Weather Radar Displays, p.48

Symbols Criteria and Standardization, p. 48

Modeling Circulation System Safety, p. 48

Security Barriers, p. 49

\section{BUILDING REHABILITATION TECHNOLOGY}

Construction Productivity for New and Rehabilitated Buildings, p. 52

Methods for Evaluating the Strength and Stability of Existing Buildings, p. 52

Regulatory Provisions for Existing Buildings, p. 52

Performance Levels for Existing Buildings, p. 53

Ventilation Criteria for Existing Buildings, p. 53

Guidelines for Venting Single-Stack Drainage Systems, p. 53

Restoration Standards for Porcelain Finishes, p. 54

Metric Conversion Scheduling in the U.S. Building Community, p. 54

Design and Construction Technology Application Program, p.54

\section{BUILDING AND COMMUNITY ACOUSTICS}

Building Acoustics Technology, p. 58

Highway Noise Criteria, p. 58

Transmission Line Audible Noise Measurement, p.58

Impact Noise Measurement, p. 59

Sound Absorption Measurement, p.59

Method for Assessing Costs of a Model Noise-Control Code, p.60

\section{BUILDING SERVICE SYSTEMS PERFORMANCE}

Plumbing Systems Performance, p. 62

Performance of Water-Conserving Devices, p. 62

Human Factors and Water Conservation, p. 62

Economically Efficient Water Conservation Standards, p. 63

Electrical Distribution Systems Protection, p. 63

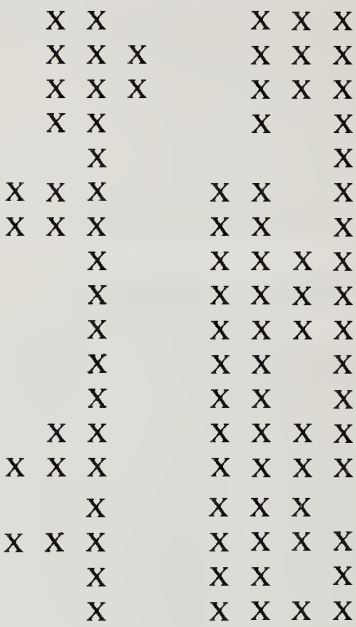

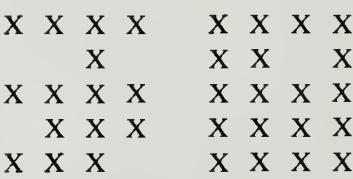

$\begin{array}{llllllllll}\mathrm{X} & \mathrm{X} & \mathrm{X} & \mathrm{X} & & \mathrm{X} & \mathrm{X} & & \mathrm{X} \\ & \mathrm{X} & \mathrm{X} & & & & \mathrm{X} & & \mathrm{X} \\ \mathrm{X} & \mathrm{X} & \mathrm{X} & & & & \mathrm{X} & & \mathrm{X} \\ \mathrm{X} & \mathrm{X} & \mathrm{X} & & & & \mathrm{X} & & \mathrm{X} \\ \mathrm{X} & \mathrm{X} & \mathrm{X} & & & & \mathrm{X} & & \mathrm{X} \\ \mathrm{X} & \mathrm{X} & \mathrm{X} & & & & \mathrm{X} & & \mathrm{X} \\ & & \mathrm{X} & & \mathrm{X} & \mathrm{X} & \mathrm{X} & \mathrm{X} & \mathrm{X} \\ \mathrm{X} & \mathrm{X} & \mathrm{X} & & \mathrm{X} & \mathrm{X} & \mathrm{X} & \mathrm{X} & \mathrm{X} \\ \mathrm{X} & \mathrm{X} & & & \mathrm{X} & \mathrm{X} & & & \mathrm{X}\end{array}$

$\begin{array}{lllllll}\mathrm{X} & \mathrm{X} & \mathrm{X} & \mathrm{X} & \mathrm{X} & \mathrm{X} & \mathrm{X} \\ \mathrm{X} & \mathrm{X} & \mathrm{X} & \mathrm{X} & \mathrm{X} & \mathrm{X} & \mathrm{X} \\ \mathrm{X} & \mathrm{X} & \mathrm{X} & \mathrm{X} & \mathrm{X} & \mathrm{X} & \mathrm{X} \\ \mathrm{X} & \mathrm{X} & \mathrm{X} & \mathrm{X} & \mathrm{X} & \mathrm{X} & \mathrm{X} \\ \mathrm{X} & \mathrm{X} & \mathrm{X} & \mathrm{X} & \mathrm{X} & \mathrm{X} & \mathrm{X} \\ & & \mathrm{X} & & & \mathrm{X} & \mathrm{X}\end{array}$

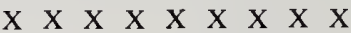

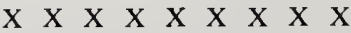

$\mathrm{X} X \mathrm{X} X \mathrm{X}$

$\begin{array}{lllll} & X & X & X & X \\ X & X & X & X & X\end{array}$ 


\section{LIGHTING TECHNOLOGY}

Lighting Design Evaluation, p.66

Task Lighting Criteria, p. 66

Measurement of Illumination Systems Effectiveness, p. 66

Laboratory and Field Illumination Measurements, p. 66

Applied Color and Vision, p. 67

Visual Environment, p. 67

Visual Techniques in NDE, p. 67

\section{BUILDING ECONOMICS}

Economic Methods for Building Standards, p. 70

Economic Impact of Electronics Research, p. 70

Quantitative Optimization Techniques, p.70

Economics Participation in Conferences, Workshops, and Seminars, p. 71

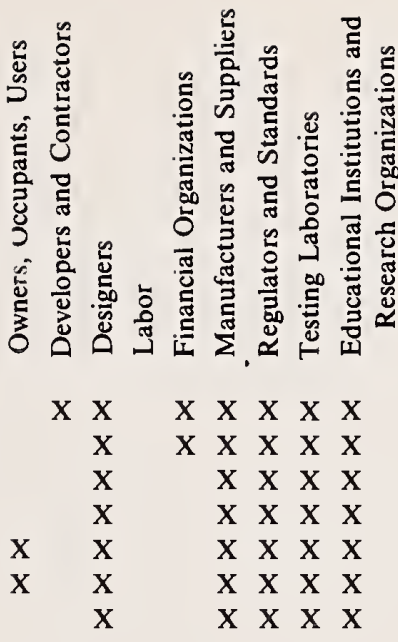

$\begin{array}{rrrrr} & \text { X } & \text { X } & \text { X } & \text { X } \\ & \text { X } & \text { X } & \text { X } & \text { X } \\ & \text { X } & \text { X } & & \text { X } \\ \text { X X X } & \text { X } & \text { X } & \text { X }\end{array}$






U.S. DEPARTMENT OF COMMERCE

National Bureau of Standards

National Engineering Laboratory

Center for Building Technology 